\title{
Polybrominated diphenyl ethers and metabolites - An analytical review on seafood occurrence
}

\author{
Rebeca Cruz a , Sara C. Cunha ${ }^{\text {a, *, }}$, António Marques ${ }^{\text {b, c }}$, Susana Casal a, d \\ a REQUIMTE, Laboratório de Bromatologia e Hidrologia, Faculdade de Farmácia, Universidade do Porto, Rua de Jorge Viterbo Ferreira 228, 4050-313, Porto, \\ Portugal \\ ${ }^{\mathrm{b}}$ IPMA, Divisão de Aquacultura e Valorização, Instituto Português do Mar e da Atmosfera, I.P., Avenida de Brasília, 1449-006, Lisboa, Portugal \\ c CIIMAR, Universidade do Porto, Rua dos Bragas 289, 4050-123, Porto, Portugal \\ d EPIUnit - ISPUP, Universidade do Porto, Rua das Taipas 135, 4050-600, Porto, Portugal
}

\section{A R T I C L E I N F O}

\section{Article history:}

Available online 18 December 2016

\section{Keywords:}

Brominated flame retardants

Polybrominated diphenyl ethers

Metabolites

Seafood

Contaminants

Chemical analysis

Food safety

\begin{abstract}
A B S T R A C T
Environmental health is systematically compromised by persistent toxic substances, which may have serious implications in terms of food safety issues and, thus, in general public health. In this context, polybrominated diphenyl ethers (PBDEs) and their biologically active metabolites have been increasingly assessed in seafood, the main route of human exposure.

As a consequence, a multiplicity of solvent-assisted analytical approaches is now available to accurately determine tiny amounts of these contaminants in complex matrices, like seafood. However, the majority of analytical procedures lead to high organic solvent consumption, thereby also contributing to the deterioration of environmental health.

The current review provides up-to-date information and critical discussion regarding the most common methodologies applied in the determination of PBDEs and their metabolites in seafood (2006 -2016), from sample preparation to instrumental analysis. The ultimate goals of this comprehensive survey are to sensitize field researchers to work under the principles of green chemistry and to improve the global consciousness on the potential necessity of their regulation in foodstuffs.
\end{abstract}

(c) 2016 Elsevier B.V. All rights reserved.

\section{Introduction}

BFRs are chemical substances that are added to a wide variety of industrial and household products to reduce their flammability.

Abbreviations: ACS, American Chemical Society; APCI, atmospheric pressure chemical ionization; BFR, brominated flame retardant; CCG, chemically converted graphene; CRM, certified reference material; CSE, conventional Soxhlet extraction; d-SPE, dispersive solid-phase extraction; ECD, electron capture detector; ECNI, electron capture negative ion; EFSA, European Food Safety Authority; EI, electron ionization; ESI, electrospray ionization; GC, gas chromatography; GCB, graphitised carbon black; GPC, gel permeation chromatography; HR, high resolution; IDL, instrumental detection limit; IS, ion spray; $\mathrm{K}_{\mathrm{OA}}$, octanol-air partition coefficient; $\mathrm{K}_{\mathrm{Ow}}$, octanol-water partition coefficient; LC, liquid chromatography; LMR, laboratory material reference; LoD, limit of detection; MAE, microwave-assisted extraction; MeO, methoxylated; MS, mass spectrometry; MSPD, matrix solid-phase dispersion; NIST, National Institute of Standards and Technology; $\mathrm{OH}$, hydroxylated; PBDE, polybrominated diphenyl ether; $\mathrm{PCB}$, polychlorinated biphenyl; $\mathrm{P}_{\mathrm{L}}$, vapour pressure; PLE, pressurized liquid extraction; PSA, primary secondary amine; PTV, programmed temperature vaporizer; QuEChERS, Quick, Easy, Cheap, Effective, Rugged and Safe; RfD, reference doses; SFE, supercritical fluid extraction; SIM, selected ion monitoring; SPE, solid-phase extraction; SPME, solid-phase microextraction; UAE, ultrasound-assisted extraction; WW, wet weight.

* Corresponding author. Fax: +351 226093390.

E-mail address: sara.cunha@ff.up.pt (S.C. Cunha).
They can be incorporated as either additives (mechanically blended with the polymeric material) or reactive ingredients (covalently attached to the polymer) [1]. Therefore, additive flame retardants may leach more easily to the environment than the reactive ones [1].

Nowadays, due to their reduced cost and recognized high efficiency and stability, PBDEs are often found in plastics, textiles and electrical/electronic equipment [1]. However, owing to environmental disposal of waste containing these additive flame retardants, PBDEs now have a widespread existence in the environment, even in locations far from where they were produced or used [2]. Moreover, due to their non-polar character, these compounds can easily suffer bioaccumulation and biomagnification, reaching all trophic levels [3-5]. Also, their toxicity in human and wildlife organisms, associated mostly with endocrine disruption [6], raised an increased legal and health concerns worldwide. In fact, many countries (e.g., European Union countries, The United Stated of America, China and Canada) have already some of these PBDEs under strict legislation (including Stockholm Convention) and surveillance in terms of their manufacture and further use in everyday life products [7-13]. 
Additionally, recent evidences of biotransformation of PBDEs, resulting in MeO-PBDEs and OH-PBDEs metabolites with identical toxicological repercussions [14], indicate that the risk of exposure to endocrine disruptors may be even greater than previously thought. Due to their structural resemblance with PBDEs, they are also environmentally persistent and have been found in various seafood species.

PBDEs comprise several brominated neutral aromatic compounds with a chemical structure consisting of two phenyl rings linked by an ether bond (Fig. 1A). The PBDE family embraces theoretically 209 congeners, sharing the same substitution pattern and congener numbering system of system of PCBs [15]. Unlike their precursors, neither OH-PBDEs nor MeO-PBDEs are intentionally synthesized or used for industrial purposes. Many hundreds of theoretical structural metabolites of PBDEs may exist under the chemical structure represented in Fig. 1B. However, analogues with a 2,4-dibromo substitution pattern (relative to the diphenyl ether bond) in the non-hydroxy-/non-methoxycontaining ring, as well as the hydroxy-/methoxy-substituted ortho to the diphenyl ether bond substitution, are the most frequently detected in the environment and biota [16]. Consequently, some of these PBDE metabolites have been frequently called as "naturally produced PBDEs" $[3,16,17]$. However, there is not enough solid evidence to support these claims, though radiocarbon studies to ascertain if the origin of these compounds is anthropogenic or natural would be of major relevance $[17,18]$.

Current understanding assumes that non-occupational human exposure to such persistent organic pollutants relies mainly on a combination of exposure through diet, ingestion/inhalation of indoor dust and inhalation of indoor air [6]. Among these, the dietary route plays a considerable role on the overall human exposure, especially from contaminated seafood consumption [19], but there are no admissible limits for the presence of PBDEs and their metabolites in food so far. Even so, in 2008, the U.S. Environmental Protection Agency has derived RfDs (i.e. an estimate of a daily oral exposure to the human population that is likely to be without an appreciable risk of deleterious effects to humans during a lifetime) for four PBDEs, for its Integrated Risk Information System [20]. RfD for PBDEs 47, 99, 153, and 209, were defined as 0.1, 0.1, 0.2 and $7 \mathrm{mg} /$ $\mathrm{kg} /$ day, respectively [20].

Throughout the past decades, owing to the recognized value of seafood as a part of a healthy diet, there has been a remarkable promotion of seafood consumption [21]. Therefore, due to its significant role to human exposure, for the past fifteen years, approximately three hundred scientific articles have been published on PBDEs presence in fishery products (based on ECsafeSEAFOOD online database, www.ecsafeseafooddbase.eu) [22]. Unfortunately, the majority of studies on PBDEs and metabolites are focused on method development with a small number of seafood samples instead of full monitoring studies to support

A<smiles>c1ccc(Oc2ccccc2)cc1</smiles>

B

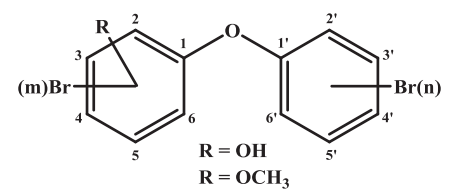

Fig. 1. The general chemical structure of (A) polybrominated diphenyl ethers $[\operatorname{Br}(\mathrm{m}, \mathrm{n})=0-5, \mathrm{~m}+\mathrm{n} \geq 1]$ and $(\mathrm{B})$ hydroxylated $(\mathrm{R}=\mathrm{OH})$ and methoxylated $\left(\mathrm{R}=\mathrm{OCH}_{3}\right)$ polybrominated diphenyl ethers $[\mathrm{Br}(\mathrm{m}, \mathrm{n})=0-5, \mathrm{~m}+\mathrm{n} \geq 1]$. environmental impact assessments. From all the studies previously revised by Cruz and co-workers [23], the highest levels of total PBDEs have been detected in benthic or benthopelagic species as common carp $(12,700 \mu \mathrm{g} / \mathrm{kg}$, WW basis $)$ or burbot $(19,970 \mu \mathrm{g} / \mathrm{kg}$, WW basis) $[24,25]$. The most frequently quantified congeners in seafood are BDE-47, -99, -100, -153, -154, -183 and -209 (Fig. 2), all included in the list of those whose production is already under regulation [9]. This fact might be related to their likely presence in the PentaBDE (e.g. DE-71, Bromkal 70-5DE) and DecaBDE (e.g. Saytex $^{\circledR} 102 \mathrm{E}$, Bromkal 82-0DE) technical mixtures extensively used in many countries until their restriction or banishment. MeOPBDEs and OH-PBDEs amounts are much more variable between studies, though the congeners found in higher concentrations are a result of both BDE-47 and -99 metabolism (Fig. 2) [26]. The authors also confirmed that total MeO-BDEs amounts reached up to $11.60 \mu \mathrm{g} / \mathrm{kg}$ (on a dry weight basis) in mackerel [26]. Despite $\mathrm{OH}-$ PBDEs are often found in lower amounts than MeO-PBDEs, substantial levels (up to $3450 \mu \mathrm{g} / \mathrm{kg}$, WW basis) were verified in blue mussels [27]. Generally, the proportion of each class varies considerably between specimens, though PBDEs are present in higher amounts (80\% of total PBDE-like compounds), followed by MeO-PBDEs (15\%) and OH-PBDEs (5\%) in seafood samples.

Being present in residual levels, a wide range of extraction and cleanup techniques, together with many instrumental approaches, have been developed and employed for their identification and quantification in seafood products. This analytical variety hardens the set-up of official guidelines to enable their assessment and,<smiles>Brc1ccc(Oc2ccc(Br)cc2Br)c(Br)c1</smiles><smiles>Brc1cc(Br)c(Oc2c(Br)cc(Br)c(Br)c2Br)cc1Br</smiles><smiles>Brc1ccc(Oc2cc(Br)c(Br)cc2Br)c(Br)c1</smiles><smiles>Brc1c(Br)c(Br)c(Oc2c(Br)c(Br)c(Br)c(Br)c2Br)c(Br)c1Br</smiles><smiles>Brc1ccc(Oc2c(Br)cc(Br)cc2Br)c(Br)c1</smiles><smiles>Oc1cc(Br)cc(Br)c1Oc1ccc(Br)cc1Br</smiles><smiles>Brc1cc(Br)c(Oc2cc(Br)c(Br)cc2Br)cc1Br</smiles><smiles>COc1cc(Br)cc(Br)c1Oc1ccc(Br)cc1Br</smiles><smiles>Brc1cc(Br)c(Oc2cc(Br)c(Br)cc2Br)c(Br)c1</smiles><smiles>COc1cc(Br)cc(Br)c1Oc1cc(Br)c(Br)cc1Br</smiles>

Fig. 2. Chemical structures of most prevalent congeners of polybrominated diphenyl ethers and metabolites. 
consequently, to define regulatory limits on their presence in food. In addition, common analytical procedures seem to be also a cause of additional damage to the environment, mostly owing to high organic solvent consumption.

In this way, it is necessary to develop reliable tools to quantify these chemicals in food products and evaluate their real toxicity, in order to sensitize and support the authorities and food industry to implement legal control measures on chemical hazards within food safety assurance schemes. For this purpose, the present review provides a critical and organized overview of the most common analytical procedures for the determination of PBDEs and their metabolites in seafood, while emphasizing potential improvements that environmental-friendly analytical approaches may bring to these assessments.

\section{Physicochemical characterization}

\subsection{Polybrominated diphenyl ethers}

In order to understand the behaviour of a specific compound in nature, namely its environmental persistency and wide spreading potential or elimination, several physicochemical features need to be taken into consideration, particularly in a huge and complex family of compounds as PBDEs. Similarly, when attempting to develop an analytical method for the assessment of a certain substance, in particular one that is present in extremely low amounts in a complex matrix, knowledge of their physicochemical features is mandatory, especially for extraction and cleanup steps.

PBDEs molecular weights vary from 249 (for mono-BDEs) to 959 (for deca-BDE) with typical ${ }^{79} \mathrm{Br}(50.5 \%)$ and ${ }^{81} \mathrm{Br}$ (49.5\%) isotope distribution patterns [28].

Hence, depending on bromination degree, ten PBDE classes may be pointed out: mono-BDEs (BDE-1, -2 and -3 ), di-BDEs (BDE-4 to BDE-15), tri-BDEs (BDE-16 to BDE-39), tetra-BDEs (BDE-40 to BDE81), penta-BDEs (BDE-82 to BDE-127), hexa-BDEs (BDE-128 to BDE169), hepta-BDEs (BDE-170 to BDE-193), octa-BDEs (BDE-194 to BDE-205), nona-BDEs (BDE-206, -207 and -208) and deca-BDE (also referred to as BDE-209). Furthermore, PBDEs exist mostly in twist or skew conformations, and the higher the degree of bromination in ortho position is, the more skewed the conformation [29].

Despite being relevant physicochemical parameters, information regarding measured melting and boiling points, instead of calculations, is scarce. Admire and colleagues [30] were able to verify a melting point variation from $19^{\circ} \mathrm{C}$ (BDE-3) to $308^{\circ} \mathrm{C}$ (BDE209) and a boiling point fluctuation from $306^{\circ} \mathrm{C}$ (BDE-3) to $411^{\circ} \mathrm{C}$ (BDE-47). No data on congeners with a high degree of bromination (more than four bromine substituents) was found.

Water solubility is a key feature that affects the transformation of a compound in water through hydrolysis, photolysis, oxidation, reduction, and biodegradation reactions [31]. Regarding PBDEs, all classes show extremely low aqueous solubility (BDE$15=0.821 \mathrm{~mol} / \mathrm{L} ; \mathrm{BDE}-209=0.002 \mathrm{~mol} / \mathrm{L}$ ), which is strongly correlated to their molecular mass and molecular volume [31]. Due to such reduced water solubility, water stability assays are nearly impossible to execute for some PBDEs (as BDE-209).

The $\mathrm{K}_{\mathrm{OW}}$ is imperative in determining the environmental fate of lipophilic organic chemicals, particularly in biota. In fact, PBDEs are highly hydrophobic, since their log Kow may achieve 8.27 in BDE183 , being tri- and tetra-BDEs those within the range of optimum bioaccumulation potential [32].

$\mathrm{K}_{\mathrm{OA}}$ is also used to describe chemicals' mobility in the atmospheric environment and can be estimated from $K_{\mathrm{OW}}$ and Henry's law constant [33]. For PBDEs, log KOA may vary from 9.30 (BDE-17) to 11.97 (BDE-156), at $25^{\circ} \mathrm{C}$, based on the assessed compounds, being also affected by molecular volume and degree of bromination
[33]. Therefore, these pollutants would not be easily transported via atmosphere. Since $\log \mathrm{K}_{\mathrm{OA}}$ is temperature-dependent, so it is PBDEs surface-air partition [33]. In fact, partition into octanol increases by an average factor of 3 for every $10^{\circ} \mathrm{C}$ decrease in temperature [33]. Therefore, the lower the atmospheric temperature is, the smaller the PBDE fraction in air. This fact helps to explain their presence in remote locations where no production sites exist, recognizing PBDEs ability to long-range atmospheric transport as a result of a series of deposition/volatilization events, known as the "grasshopper effect", which is also enhanced by vegetation air-surface exchange [34].

Another crucial property in terms of physicochemical characterization is $P_{\mathrm{L}}$, which allows predicting behaviour of organic micro contaminants in the environment and calculating Henry's law constants [31]. Despite vapour pressure may vary according to the experimental method used for its assessment, the increase of molecular volume and number of substituted bromine at the ortho position results in a linear reduction of a certain PBDE vapour pressure [31]. Hence, $\log P_{\mathrm{L}}$ may range from around -0.7 (BDE-1) to -6.2 (BDE-190), thus corroborating their low volatility [31].

\subsection{Metabolites}

Similar to their precursors, OH-PBDEs and MeO-PBDEs show a high bioaccumulative and biomagnificative potential due to their high $\log \mathrm{K}_{\mathrm{OW}}$. For instance, among the tested MeO-PBDEs, 6-MeOBDE-17 presented the lowest lipophilicity $\left(\log \mathrm{K}_{\mathrm{OW}}=5.74\right)$ and 6 $\mathrm{MeO}-\mathrm{BDE}-138$, the highest $\left(\log \mathrm{K}_{\mathrm{OW}}=7.67\right)$ [35]. In addition, from the analysed OH-PBDEs, 6-OH-BDE-138 was the most hydrophobic $\left(\log \mathrm{K}_{\mathrm{OW}}=7.17\right)$, and 2-OH-BDE-7, the least $(\log$ $\left.\mathrm{K}_{\mathrm{OW}}=4.63\right)[35]$.

No data was found regarding $\log P_{\mathrm{L}}$ of OH-PBDEs or MeO-PBDEs, though $\log \mathrm{K}_{\mathrm{OA}}$ varied from 8.30 (2'-OH-BDE-3) to 13.29 (6-OHBDE-157), for HO-BDEs, and from 10.16 (2'-MeO-BDE-28) to 13.00 (6-MeO-BDE-157), for MeO-PBDEs [36].

While PBDEs and MeO-PBDEs are known as neutral compounds, OH-PBDEs present a predictive $\mathrm{pK}_{\mathrm{a}}$ that range from 4.2 to 9.3 [37], depending on the substitution pattern (ortho-, meta-or para-substitution) of both bromine and hydroxyl substitutes and bromination degree. Hence, during sample extraction/cleanup, if the matrix is not acidified to a pH below 4, then extraction of all OH-PBDEs may not be fully accomplished [37].

\section{Environmental degradation}

Current knowledge indicates that the major PBDEs degradation products or metabolites are less-brominated PBDEs, OH-PBDEs and MeO-PBDEs. Due to their strong hydrophobicity and low solubility in water, PBDEs reveal high partition affinity to organic matrices/ solvents. In general, higher brominated BDEs degrade faster than less-brominated ones in apolar solvents, though different degradation rates occur within the same bromine number PBDE class [38]. Furthermore, PBDEs photoreactivity order is generally meta $\geq$ ortho $>$ para, particularly for PBDEs with less than eight bromines [38]. Also, photoreactivity of PBDEs is lower in poor hydrogen-donating solvents, as tetrahydrofuran, being debromination the main mechanism of PBDEs photolysis in organic solvents [38]. On the other hand, in natural aquatic environment, photochemical behaviour depends strongly on concomitant chemical species, such as humic substances, metal and halide ions, often generating OH-PBDEs, chlorinated PBDEs, besides the lessbrominated PBDEs [38]. In the atmosphere, photochemical transformation of PBDEs can be described as direct photolysis and photooxidation by $\mathrm{OH}$ radicals, thus resulting in the formation of OH-PBDEs [38]. 


\section{Sampling and sample preparation}

Food matrices are known to be highly heterogeneous, being composed by water, carbohydrates, fats, proteins, and minerals, which also count with a potential diversity of micronutrients, additives and contaminants. This complexity may be even further increased after food thermal processing. As a consequence, food samples are inherently difficult to analyse accurately.

From an analytical point of view, seafood is amongst the most complex food products, not only due to its chemical composition but also owing to what is considered as being edible (e.g. muscle, muscle plus skin or whole body with or without viscera, all depending on the species under study and dietary habits). Additionally, the size of the food portion to be analysed, as well as the seafood tissues/organs represent key points in the overall analytical process, especially when attempting to estimate the dietary intake of a certain nutrient or contaminant.

In order to obtain a representative and homogeneous laboratory sample, without secondary contamination, EFSA advises the analysts to proceed according to the provisions set out for dioxins and dioxin-like PCBs in food [39]. This regulation provides a number of requirements regarding sampling methods for seafood and other goods, defining precautionary measures during sampling, the size of the lot, packaging, transport, storage, sealing and labelling. From therein, some key points may be highlighted as collecting fish of comparable size and weight, i.e. differences do not exceed 50\% [39]. Moreover, collection of incremental samples may vary according to fish size [39]. Still, when sampling fish muscle, care should be taken that no epidermis or subcutaneous fatty tissue are included in the sample [28]. If liver dissection is intended, care should be taken to avoid contamination from other organs [28]. If bile samples are to be taken, they should be collected first [28].

Regarding shellfish sampling, a 24 h depuration may be required to void the gut contents of any associated contaminants before freezing or sample preparation, depending on the purpose of the study [28]. Shellfish should be shucked, live if possible, and opened with minimal tissue damage, by detaching the adductor muscles from the interior of at least one valve [28].

No sampling or sample preparation recommendations were found for other types of seafood, as cephalopods or crustaceans. Nevertheless, selection of target species should also attend some empiric criteria as potential bioaccumulation capacity, geographic distribution, easier identification as possible, abundance, easy capture, distinct trophic levels and habitats, and adequate size to provide acceptable tissue for analysis. Also, considering the increasing presence of PBDEs and active metabolites, seafood consumption patterns should also be considered.

\subsection{Pre-extraction determinations}

Aiming to characterize samples and report their concentrations in biota on a dry-weight or lipid-weight basis, moisture and lipid contents are usually evaluated prior to extraction. Dry weight should be determined gravimetrically, while the total lipid content of seafood is often determined using CSE. Meanwhile, extracted lipids may be further used for analysis, if protective measures are taken during extraction. Otherwise, the lipid content should be determined on a separate subsample of the tissue homogenate. Seafood samples must then be frozen, at $-20^{\circ} \mathrm{C}$ or lower, freezedried (optional) and protected from light until analysis [28].

\section{Extraction and cleanup}

While sample preparation steps remain nearly identical (e.g., sample fraction collection, freezing, freeze-drying), extraction and cleanup procedures have been moving towards time- and costeffective multi-residue analysis with the lowest possible LoD. However, the majority of available analytical methodologies are still far from being fully considered as environmental-friendly, especially due to the high solvent consumption.

The concept of "Green Chemistry" was firstly defined by Anastas and Warner as the design of chemical products and processes that minimize or eliminate the generation of harmful substances to the environment and humans [40]. The first principle of green chemistry, defined as "Prevention", brings awareness on the prevention of waste, rather than its posterior treatment or cleaning [40]. Therefore, the use of solventless extraction techniques, application of direct determination methodologies, and miniaturization are envisaged. However, for chromatographic determinations, the former procedures can only be applied to relatively clean matrices, as otherwise the chromatographic columns would easily deteriorate due to deposition of non-eluted sample components. Therefore, although molecularly-imprinted polymers have shown good outcomes for abiotic matrices [41], the use of solventless extraction and cleanup methods for PBDEs analysis in seafood is still far from optimized.

\subsection{Extraction methods}

The most frequently used techniques for the extraction of PBDEs and metabolites in seafood are presented in Fig. 3, which gathers data from 140 published scientific papers in ACS, Elsevier, Taylor \& Francis and Wiley, regarding seafood contamination by PBDEs, from 2006 to 2016. The keywords used for this research were: "polybrominated diphenyl ether", "PBDE", "fish", and "seafood".

It is very clear that, in 2006, CSE was the most popular extraction method for PBDE and metabolites analysis in seafood (Fig. 3). Nevertheless, there has been a well-defined trend in using more environmental-friendly methods with PLE and UAE gaining ground over the most conventional ones. Other extraction methods, as highlighted in Fig. 3 are QuEChERS approaches, MSPD, MAE and SFE.

\subsubsection{Conventional Soxhlet Extraction}

This technique consists of an exhaustive thermal extraction of organic analytes by an apolar solvent, semi-continuously refluxed through the sample, in a Soxhlet system. This cycle may be allowed to repeat over a few hours or even days.

Regarding PBDEs and derivatives in seafood, CSE usually lasts $21 \mathrm{~h}$, on average (Table 1 ), but it may reach $72 \mathrm{~h}$ of extraction [42].

aCSE $\square$ PLE $\square$ UAE $\square$ Other techniques

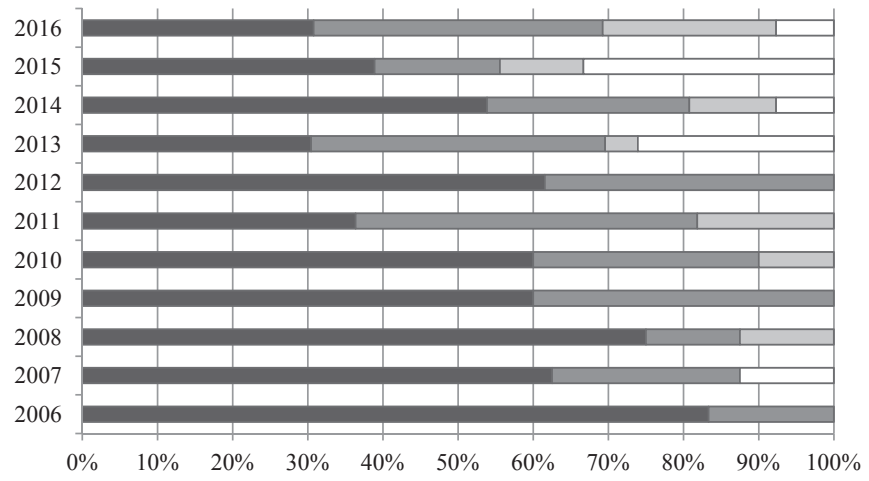

Fig. 3. Time-trend (2006-2016) representation of the extraction techniques most used in polybrominated diphenyl ethers analysis in seafood. CSE, Conventional Soxhlet Extraction; PLE, Pressurized Liquid Extraction; UAE, Ultrasound-Assisted Extraction. 
Table 1

Summary of selected reported studies from the past decade regarding CSE of PBDEs and their metabolites in seafood.

\begin{tabular}{|c|c|c|c|c|c|c|c|}
\hline Solvent & Ratio & $\begin{array}{l}\text { Extractive } \\
\text { volume }(\mathrm{mL})\end{array}$ & Sample (g) & $\begin{array}{l}\text { Time } \\
\text { (h) }\end{array}$ & Congeners & Matrix & Ref. \\
\hline \multirow[t]{4}{*}{ HEX:DCM } & $1: 1$ & 180 & 4, DW & 24 & $17,28,71,47,66,100,99,85,154,153,138,183,190$ & Muscle, liver and eggs & [47] \\
\hline & & 200 & 3, DW & 48 & Total PBDEs $(\Sigma 9)$ & Muscle & [66] \\
\hline & & - & $20, \mathrm{WW}$ & 16 & $\begin{array}{l}15,17,28,47,49,66,71,77,85,99,100,119,126,138,153,154,155 \\
166,181,183,190,203,204,205,206,207,209\end{array}$ & Muscle & [92] \\
\hline & $5: 1$ & 120 & $3-5, \mathrm{DW}$ & 20 & $28,47,99,100,153,154,183$ & Muscle & [93] \\
\hline \multirow[t]{5}{*}{ HEX: ACT } & $1: 1$ & 400 & 5, DW & 72 & Total PBDEs $(-)$ & Muscle & [42] \\
\hline & & 200 & $12, \mathrm{WW}$ & 48 & Total PBDEs $(\Sigma 7)$ & Muscle & [54] \\
\hline & $3: 1$ & 100 & $10, \mathrm{WW}$ & 2 & Total PBDEs $(\Sigma 7)$ & Muscle and whole body & [83] \\
\hline & $4: 1$ & 350 & - & 7 & Total PBDEs $(\Sigma 11)$ & $\begin{array}{l}\text { Muscle and whole body } \\
\text { (zooplankton) }\end{array}$ & [84] \\
\hline & & - & 10, DW & 16 & $28,47,99,100,153,154,183 ; 5-\mathrm{MeO}-47,6-\mathrm{MeO}-47,2^{\prime}-\mathrm{MeO}-68$ & Muscle & [94] \\
\hline \multirow[t]{3}{*}{ DCM: ACT } & $1: 1$ & 80 & $5, \mathrm{DW}$ & 12 & $15,17,28,47,66,99,100,153,154,183,209$ & Muscle and liver & [95] \\
\hline & & - & 1.5, DW & 18 & $\begin{array}{l}3,7,15,17,28,47,49,66,71,77,85,99,100,119,126,138,153,154, \\
156,183,184,191\end{array}$ & Muscle & [46] \\
\hline & & 100 & $\begin{array}{l}\text { 2, DW (muscle); } \\
\text { 1, WW (liver) }\end{array}$ & 24 & $\begin{array}{l}3,7,15,17,28 \\
47,49,66,71,77,85,99,100,119,126,138,153,154,156,183,184, \\
\text { 191, 196, 197, 206, 207, 209; 5-MeO-47, 6-MeO-47, 4-MeO-49, } \\
\text { 2-MeO-68, 5-MeO-99, 5-MeO-100, 4-MeO-101, 4-MeO-103 }\end{array}$ & Muscle and liver & [96] \\
\hline $\begin{array}{l}\text { Diethyl ether: } \\
\text { HEX }\end{array}$ & - & - & 15-30, DW & $7-8$ & Total PBDEs $(\Sigma 14)$ & Whole body & [55] \\
\hline TOL & - & - & $40, W W$ & 20 & $28,47,88,99,153,183$ & Muscle and whole body & [97] \\
\hline DCM & - & - & $1-3, \mathrm{DW}$ & 12 & $47,66,85,99,100,153,154,183$ & $\begin{array}{l}\text { Muscle, liver, spleen, } \\
\text { stomach, stomach } \\
\text { content, blood, egg, } \\
\text { gallbladder }\end{array}$ & [98] \\
\hline
\end{tabular}

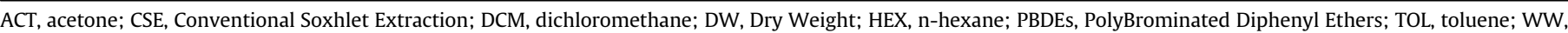
Wet Weight.

Despite the fact that Soxhlet system dimension may vary, the common procedures often use $80-400 \mathrm{~mL}$ of organic solvent to extract PBDEs and their derivatives from 3 to $5 \mathrm{~g}$ (on a dry weight basis) of fish muscle tissue (Table 1). Since these pollutants present very high $\log \mathrm{K}_{\mathrm{OW}}$, lipid-rich matrices are more prone to present higher level of contamination. This implies that, when contaminants with high $\log \mathrm{K}_{\mathrm{OW}}$ are analysed in samples with high lipid content, a lower sample intake is required for quantification [43]. Therefore, the amount of sample used for analysis heavily relies on the matrix fat content, which is applied for all extraction methods.

Together with $\log \mathrm{K}_{\mathrm{OW}}$, knowledge of the relative solubility of target analytes in various solvents can form the extraction and cleanup method basis. Binary solvent mixtures normally containing n-hexane:dichloromethane and n-hexane:acetone, in different proportions (often 1:1, 3:1 and 4:1, v/v), with an average volume of $165 \mathrm{~mL}$ per sample, are usually preferred for CSE, but single solvent extraction with toluene or dichloromethane is also observed (Table 1).

Despite CSE advantages, as operative availability, robustness and simplicity, this technique leads to high solvent and time consumptions that are not compatible to the green chemistry demands. In addition, the final extracts require further cleanup steps prior to instrumental analysis.

\subsubsection{Pressurized Liquid Extraction}

Aiming to overcome some CSE limitations, PLE (or Automated Soxhlet Extraction, ASETM, traded by Dionex Corporation) brought major green chemistry improvements. PLE is used for extraction of solid samples by using a liquid-phase at high pressure and/or temperature, but below its critical state. Briefly, the efficiency of extraction depends on the solvent/sample ratio, sample composition, particle size (preferably below $0.4 \mathrm{~mm}$ ) and extraction time, as was with CSE [44].

Sample size and extraction solvents employed in PBDEs and metabolites analysis are usually the same as the ones used in CSE, where n-hexane:dichlorometane $(1: 1, v / v)$ or single dichloromethane stand out (Table 2). Aware of the known dichloromethane toxicity, despite being lower than that of chloroform used in the most classical lipid extraction methods in seafood (Bligh and Dyer or Folch methods), it is remarkable that this halogenated solvent is still so frequently used in "environmental-friendly" methods. However, since the extraction is carried out in closed-vessels under pressure (7-12 $\mathrm{MPa}$ ) and at high temperatures $\left(90-150^{\circ} \mathrm{C}\right)$, approaching a supercritical state, it can be faster (6-60 min) and use less organic solvent $(50-100 \mathrm{~mL}$, depending on solvent flow rate and number of cycles) than CSE (Table 2).

PLE systems may be used in static or flow-through modes. Despite being less efficient than the latter, static mode is often preferred by analysts to avoid extract dilution and reduce solvent consumption [44]. Other advantages of PLE are its autonomy (several samples can be processed sequentially), different sample sizes or extraction volume can be accommodated (e.g. 11-100 mL vessels are available, though $22 \mathrm{~mL}$ are more commonly chosen, Table 2 ).

Although its use is becoming more frequent (Fig. 3), PLE apparatus is still very expensive, less robust than CSE and extracts also require subsequent cleanup. Nevertheless, PLE selectivity may be increased by loading sorbents in the outlet end of sample cell, so undesired substances may be retained by the sorbent, thus providing an in-cell cleanup.

\subsubsection{Ultrasound-Assisted Extraction}

UAE is the simplest solid-liquid (or liquid-liquid, depending on sample nature) extraction method, which is carried out by blending the solid sample with an appropriate organic solvent and promoting "cavitation", using an ultrasonic bath or a closed extractor fitted with a sonic probe, the latter leading to more reproducible results.

The "cavitation" process consists on the formation and implosion of vacuum micro bubbles through the solvent, creating hotspots with high temperatures and pressures (estimated up to $4726^{\circ} \mathrm{C}$ and $100 \mathrm{MPa}$ ), thus accelerating chemical reactivity of the medium [44]. As a consequence, the solvent penetrates more easily into solid materials and a mass transfer from inside out the matrix cells occurs, therefore enhancing extraction efficiency. 
Table 2

Summary of selected reported studies from the past decade regarding PLE of PBDEs and their metabolites in seafood.

\begin{tabular}{|c|c|c|c|c|c|c|c|}
\hline Solvent & Ratio & Sample (g) & Time $(\mathrm{h})$ & Other features & Congeners & Matrix type & Ref. \\
\hline \multirow[t]{6}{*}{ HEX:DCM } & \multirow[t]{6}{*}{$1: 1$} & - & 0.3 & $\begin{array}{l}\text { Static mode, } 100 \mathrm{~mL} \text { vessel, } \\
\mathrm{T}=125^{\circ} \mathrm{C}, \mathrm{P}=10 \mathrm{MPa}\end{array}$ & $47,55,99,100,153$ & $\begin{array}{l}\text { Muscle, whole soft tissue } \\
\text { and whole body } \\
\text { (zooplankton) }\end{array}$ & [5] \\
\hline & & $1, \mathrm{DW}$ & 0.85 & $\begin{array}{l}\text { Static mode, } 22 \mathrm{~mL} \text { vessel, } \\
\mathrm{T}=100^{\circ} \mathrm{C}, \mathrm{P}=10 \mathrm{MPa}\end{array}$ & $28,47,49,66,99,100,119,140,153,154,183,209$ & Muscle & [65] \\
\hline & & $1, \mathrm{DW}$ & - & $\begin{array}{l}\text { Static mode, } \mathrm{T}=100^{\circ} \mathrm{C} \\
\mathrm{P}=13.7 \mathrm{MPa}\end{array}$ & $28,47,99,100,153,154,183$ & Muscle & [81] \\
\hline & & $5, \mathrm{DW}$ & 0.1 & $\begin{array}{l}\text { Static mode, } \mathrm{T}=110^{\circ} \mathrm{C} \\
\mathrm{P}=10 \mathrm{MPa}\end{array}$ & $28,47,99,100,153,154,183,209$ & $\begin{array}{l}\text { Muscle and whole soft } \\
\text { tissue }\end{array}$ & [99] \\
\hline & & 2, DW & - & $12 \mathrm{~mL}$ vessel, $\mathrm{T}=90^{\circ} \mathrm{C}$ & $\begin{array}{l}17,28,47,66,85,99,100,153,154,183,197,201,202, \\
203,206,207,208,209\end{array}$ & Whole body & [67] \\
\hline & & 2, DW & - & $\mathrm{T}=150^{\circ} \mathrm{C}, \mathrm{P}=10 \mathrm{MPa}$ & $17,28,47,66,85,99,100,138,153,154,183$ & Muscle & [58] \\
\hline \multirow[t]{3}{*}{ DCM } & \multirow[t]{3}{*}{-} & 0.5 , DW & 0.25 & $\begin{array}{l}\text { Static mode, } 22 \mathrm{~mL} \text { vessel, } \\
\mathrm{T}=100^{\circ} \mathrm{C}, \mathrm{P}=13 \mathrm{MPa}\end{array}$ & Total PBDEs $(\Sigma 4)$ & Muscle & [63] \\
\hline & & \multirow[t]{2}{*}{-} & \multirow[t]{2}{*}{0.33} & $\mathrm{~T}=100^{\circ} \mathrm{C}, \mathrm{P}=6.9 \mathrm{MPa}$ & Total PBDEs $(\Sigma 11)$ & Muscle & [100] \\
\hline & & & & $\begin{array}{l}\text { Static mode, } 22 \mathrm{~mL} \text { vessel, } \\
\mathrm{T}=100^{\circ} \mathrm{C}, \mathrm{P}=13.8 \mathrm{MPa}\end{array}$ & $\begin{array}{l}28,30,33,47,75,85,99,153,154,155 ; 6-\mathrm{MeO}-47 \\
2^{\prime}-\mathrm{MeO}-68\end{array}$ & Muscle & [101] \\
\hline \multirow[t]{2}{*}{ HEX: ACT } & - & - & 0.25 & $\begin{array}{l}\text { Static mode, } \mathrm{T}=120^{\circ} \mathrm{C} \\
\mathrm{P}=10 \mathrm{MPa}\end{array}$ & $\begin{array}{l}28,47,66,71,77,85,99,100,119,138,153,154,183 \\
190\end{array}$ & Muscle & [64] \\
\hline & $4: 1$ & $5-10, \mathrm{WW}$ & 0.35 & $\begin{array}{l}\text { Static mode, } \mathrm{T}=100^{\circ} \mathrm{C} \\
\mathrm{P}=10.3 \mathrm{MPa}\end{array}$ & $\begin{array}{l}1,2,3,7,8,10,11,12,13,15,17,25,28,30,3233,35, \\
37,47,49,66,71,75,77,85,99,100,116,118,119,126, \\
\text { 138, 153, 154, 155, 166, 181, 183, 190; 2'-MeO-28, } \\
4^{\prime}-\mathrm{MeO}-17,6-\mathrm{MeO}-47,6^{\prime}-\mathrm{MeO}-66,2^{\prime}-\mathrm{MeO}-74, \\
2^{\prime}-\mathrm{MeO}-75 ; 4^{\prime}-\mathrm{OH}-17,6-\mathrm{OH}-47,6^{\prime}-\mathrm{OH}-66,2^{\prime}-\mathrm{OH}-74, \\
2^{\prime}-\mathrm{OH}-75\end{array}$ & Whole body & [86] \\
\hline HEX & - & $25-50, \mathrm{DW}$ & 0.7 & $\mathrm{~T}=125^{\circ} \mathrm{C}, \mathrm{P}=10 \mathrm{MPa}$ & $28,47,29,66,99,100,153,154,183$ & $\begin{array}{l}\text { Muscle, liver, gonads and } \\
\text { adipose tissue }\end{array}$ & [102] \\
\hline ETN: TOL & $1: 5$ & - & - & - & $\begin{array}{l}28,47,66,71,75,77,85,99,100,119,138,153,154, \\
183,209\end{array}$ & Muscle and/or bone & [103] \\
\hline
\end{tabular}

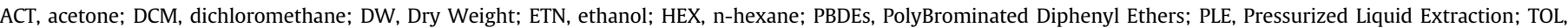
toluene; WW, Wet Weight.

In general, the extraction efficiency is dependent upon ultrasound frequency, temperature, sonication time, extractive solvent and matrix nature, as well as sample particle size [44].

A pronounced advantage in comparison to the previous methods is that UAE allows extraction of large amounts of sample with a relatively low cost, usually being as fast as PLE (less than $1 \mathrm{~h}$ ) and requires lower solvent volumes (5-90 mL, Table 3). However, it does not allow automation and the extractive solvents are commonly the same as those used in CSE and PLE.

\subsubsection{Other extraction methods}

Another extraction method that has been demonstrated to be an interesting alternative for extraction of PBDEs is MAE. This technique employs non-ionizing radiation $(0.3-300 \mathrm{GHz})$ that causes molecular motion by ionic conduction and rotation of dipoles in both solvent and sample, resulting in thermal energy generation [44]. If a certain molecule presents relatively high dielectric constant, then the oscillation in the microwave field is more intense, causing dipole rotation and disruption of weak hydrogen bonds. Furthermore, polar solvents with high dielectric losses, such as water, are more efficient in producing heat, and so samples are usually dried prior to extraction to avoid overheating. On the contrary, non-polar solvents as n-hexane will not produce thermal energy. Therefore, it is of common practice the use of a binary mixture (e.g., n-hexane:dichloromethane $1: 1, v / v$ ) where only one of the solvents absorbs microwaves. Moreover, the higher the viscosity of the medium is, the lower the molecular rotation [44].

MAE may be performed in closed vessels under pressure (pressurized MAE) or in open vessels at atmospheric pressure (focused MAE). Although the former is less safe in terms of sample handling, it provides enhanced extraction speed and efficiency, being the most used MAE system in contaminants analysis. Briefly, the efficiency of extraction depends on the solvent (nature and solvent/sample ratio), temperature and pressure, extraction time, power, sample composition (moisture) and particle size (preferably
0.1-2 mm) [44]. This extractive technique also presents a reduced extraction time (around 15 min per batch of as many as 40 samples) and uses small amounts of solvents ( $40 \mathrm{~mL}$ in MAE, Table 4). However, the equipment is considerably expensive, the extract must be filtered after extraction, and further cleanup steps are generally needed.

While for other methods pressure control is not a crucial step (as its role is just to keep the extractive solvent in its liquid state), for SFE it is fundamental. This method implies the use of an extractive gas in its supercritical state, usually carbon dioxide (at around $31^{\circ} \mathrm{C}$ and 7.4 MPa), which results in a fluid that has higher diffusivity, thus it presents a higher solvating power and may extract analytes faster and more efficiently than liquids, providing solvent-free extracts. Briefly, extraction yield depends on solvent flow rate, sample composition, particle size, solubility (pressure and temperature balance) and the use of polarity modifiers [44].

Indeed, SFE provides highly selective extractions, by altering the density of the extractive fluid through pressure and temperature adjustments, resulting in cleaner extracts than those obtained by PLE, where co-extraction of matrix lipids is nearly inevitable. When intended, extraction selectivity may be further improved by using polar modifiers (e.g. ethanol, acetone or methanol), thus increasing the solvating power and reducing the analyte-matrix interactions [44]. Similarly to CSE and PLE, water removal from sample matrix is advised, since it negatively affects extraction [44].

Despite being a more environmental-friendly technique, SFE is still extremely expensive, reducing its widespread use and no papers on this matter were found during the period 2006-2016. Notwithstanding, in 2005, Rodil and co-workers [45] developed a SFE-based multiresidue analytical methodology that was combined with SPME for the assessment of several halogenated contaminants, including PBDEs, in seafood.

Finally, regardless of the method chosen for contaminants extraction, addition of internal standards should be done at this stage of the analytical procedure. 
Table 3

Summary of selected reported studies from the past decade regarding UAE of PBDEs and their metabolites in seafood.

\begin{tabular}{|c|c|c|c|c|c|c|c|}
\hline Solvent & Ratio & $\begin{array}{l}\text { Extractive } \\
\text { volume }(\mathrm{mL})\end{array}$ & Sample (g) & $\begin{array}{l}\text { Time } \\
\text { (h) }\end{array}$ & Congeners & Matrix type & Ref. \\
\hline \multirow[t]{4}{*}{ HEX:DCM } & $1: 1$ & 90 & $5-15, W W$ & 1 & $\begin{array}{l}17,28,47,49,66,85,99,100,101,118,126,153 \\
154,155,183\end{array}$ & $\begin{array}{l}\text { Muscle, whole soft tissue } \\
\text { and whole body (small } \\
\text { fishes) }\end{array}$ & [53] \\
\hline & & 40 & 3, DW & 0.85 & $\begin{array}{l}3,7,15,17,28,47,49,66,71,77,85,99,100 \\
119,126,138,153,154,156,183,184,191,194 \\
195,196,201,202,205,206,207,208,209\end{array}$ & Muscle & [57] \\
\hline & & 30 & 1, DW & 0.17 & $\begin{array}{l}3^{\prime}-\mathrm{OH}-7,3^{\prime}-\mathrm{OH}-28,4^{\prime}-\mathrm{OH}-17,2^{\prime}-\mathrm{OH}-28 \\
3-\mathrm{OH}-47,5-\mathrm{OH}-47,4^{\prime}-\mathrm{OH}-49,6-\mathrm{OH}-47\end{array}$ & Muscle & [51] \\
\hline & $4: 1$ & 8 & 1, WW & 0.5 & $47,99,100,153$ & Muscle & {$[60]$} \\
\hline HEX:Methyl tert-butyl ether & $1: 1$ & 5 & 1, DW & 0.5 & $\begin{array}{l}\text { 28, 47, 66, 68, 85, 99, 138, 153, 154, 183; } \\
\text { 2'-MeO-68, 6-MeO-47, 3-MeO-47, 5-MeO-47, } \\
\text { 4'-MeO-49, 4-MeO-42, 6'-MeO-99, 5'-MeO-99, } \\
\text { 6-MeO-85; 3'-OH-28, 4-OH-42, 3-OH-47, } \\
\text { 4'-OH-49, 5-OH-47, 6-OH-47, 2'-OH-68, } \\
\text { 6-OH-85, 5-OH-99, 6'-OH-99 }\end{array}$ & $\begin{array}{l}\text { Muscle and whole soft } \\
\text { tissue }\end{array}$ & [69] \\
\hline ACT:cHEX:water $\rightarrow$ ACT:cHEX & $3: 4: 2 \rightarrow 1: 2$ & 60 & - & - & $28,47,99,100,153,154$ & Liver & [25] \\
\hline cHEX:ACT & $3: 2$ & - & 4-7, WW & - & Total PBDEs $(\Sigma 10)$ & Muscle & [76] \\
\hline ACN:TOL & $9: 1$ & 5 & $2.5, \mathrm{DW}$ & - & $28,47,99,100,153,154,183,209$ & $\begin{array}{l}\text { Muscle and whole soft } \\
\text { tissue }\end{array}$ & [68] \\
\hline ACN & - & 5 & $5, \mathrm{WW}$ & 0.9 & $28,47,99,100,153,154,183$ & Fish liver and gonads & {$[104]$} \\
\hline
\end{tabular}

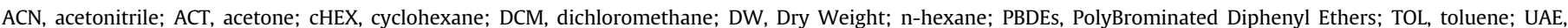
Ultrasound-Assisted Extraction; WW, Wet Weight.

Table 4

Summary of selected reported studies from the past decade regarding MAE and QuEChERS of PBDEs in seafood.

\begin{tabular}{|c|c|c|c|c|c|c|c|c|c|}
\hline Method & Solvent & Ratio & $\begin{array}{l}\text { Extractive } \\
\text { volume }(\mathrm{mL})\end{array}$ & Sample (g) & $\begin{array}{l}\text { Time } \\
\text { (h) }\end{array}$ & $\begin{array}{l}\text { Other } \\
\text { features }\end{array}$ & Congeners & Matrix type & Ref. \\
\hline \multirow[t]{2}{*}{ MAE } & HEX:DCM & $1: 1$ & 40 & $0.25, \mathrm{WW}$ & 0.25 & $\mathrm{~T}=115^{\circ} \mathrm{C}$ & Total PBDEs $(-)$ & Muscle & [105] \\
\hline & $\begin{array}{l}\text { Nitric acid: } \\
\text { hydrochloric acid }\end{array}$ & $4: 1$ & 15 & $1-2, \mathrm{WW}$ & - & - & Total PBDEs $(\Sigma 8)$ & Muscle & {$[56]$} \\
\hline \multirow[t]{5}{*}{ QuEChERs } & ACN & - & 10 & $10, \mathrm{WW}$ & - & - & Total PBDEs $(\Sigma 7)$ & Muscle & [106] \\
\hline & & & & $10, \mathrm{WW}$ & - & - & $28,99,100,153,154$ & Muscle & [107] \\
\hline & & & 4 & 4, DW & - & - & $28,47,99,100,153,154$ & Muscle & [108] \\
\hline & & & 5 & 5, WW & 0.9 & - & $28,47,99,100,153,154,183$ & Fish liver and gonads & [104] \\
\hline & Ethyl acetate & - & 10 & $10, \mathrm{WW}$ & 0.12 & - & $\begin{array}{l}28,37,47,49,66,77,85,99,100 \\
153,154,183,196,197,203,206 \\
207,209\end{array}$ & Fish muscle & [109] \\
\hline
\end{tabular}

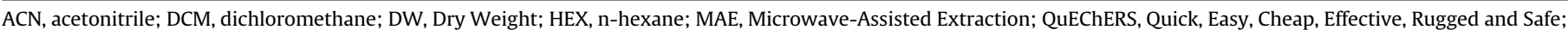
PBDEs, PolyBrominated Diphenyl Ethers; TOL, toluene; WW, Wet Weight.

\subsection{Cleanup methods}

Even after selecting and optimizing the extraction procedure, several matrix components (e.g. lipids) or compounds with physicochemical similarities with our analyte might still remain in the extract. They must be removed to ensure a more accurate identification and sensitive quantification of PBDEs and metabolites, as well as to minimize deterioration of instrumental performance. The cleanup methods used for the analysis of this type of contaminants are often categorized as destructive (e.g. strong acid or alkaline treatment) or non-destructive methods for lipid removal (e.g. GPC or SPE)

\subsubsection{Sulphur removal}

Sulphur should be removed from sample extracts, to minimize interferences and to protect the detectors. This can be easily accomplished by adding copper powder during (and sometimes after) CSE or PLE, but it can also be removed by GPC. Sediment, soil and sewage sludge often contain significant amounts of this element, but the same does not happen for seafood. Yet, it is occasionally used as a precaution measure in the cleanup of seafood extracts $[5,46,47]$.

\subsubsection{Acid and alkaline treatments}

Since PBDEs and MeO-PBDEs are stable under strong acid conditions, sulphuric acid or hydrochloric acid are frequent destructive treatments used to ensure an efficient removal of lipid matter. Lipid destruction in acidic conditions is commonly performed by adding acid directly to the sample extract (dissolved in an organic solvent) [48-50], which clearly leads to several liquid-liquid extractions and centrifugation steps, turning it into a laborious and longstanding approach. However, as previously highlighted (see section "Physicochemical Characterization), adequate recovery of $\mathrm{OH}$ PBDEs can only be assured if acidification of sample extract is conducted prior to cleanup [37,51].

For seafood, other destructive methods for lipid removal, such as saponification with alcoholic alkalis (sodium or potassium hydroxide), have also been investigated $[4,48]$, but it may result in losses of bromine atoms from highly brominated PBDEs [52].

\subsubsection{Gel permeation chromatography}

This method, also known as size exclusion chromatography, is based on molecular size separation and is mainly used to remove lipid material (greater than $500 \AA$ ) from sample extracts. When applied to the analysis of PBDEs and their derivatives in seafood, GPC often use Bio-Beads S-X3 (200-400 mesh, 2000 Da limit) gels in polystyrene-divinylbenzene columns and dichloromethanebased mixtures as eluent (Table 5).

In general, single GPC is sufficiently effective in isolating target compounds from co-extracted lipids (less than 5\% lipid content) [53]. However, more complex matrices may require the 
Summary of selected reported studies from the past decade on cleanup methods for PBDEs and their metabolites analysis in seafood.

\begin{tabular}{|c|c|c|c|c|c|c|c|}
\hline Analytical method & Organic solvents $(\mathrm{mL})^{\mathrm{a}}$ & Other features (top to bottom) & Matrix type & Fat content (\%) & Congeners & $\begin{array}{l}\text { Recovery } \\
(\%)\end{array}$ & Ref. \\
\hline \multirow[t]{3}{*}{ CSE - SPE } & HEX:DCM 7:3 (50) & $\begin{array}{l}\mathrm{H}_{2} \mathrm{SO}_{4} \rightarrow \text { anh. } \mathrm{Na}_{2} \mathrm{SO}_{4} \rightarrow \text { activated } \\
\text { copper } \rightarrow \text { activated silica }\end{array}$ & Muscle & $0.01-29.1$ & $\begin{array}{l}3,7,15,17,28,47,49,66,71,77,85,99,100 \\
119,126,138,153,154,156,183,184,191\end{array}$ & $76-108$ & [46] \\
\hline & HEX:DCM 1:9 (50) & $\mathrm{H}_{2} \mathrm{SO}_{4} \rightarrow$ anh. $\mathrm{Na}_{2} \mathrm{SO}_{4} \rightarrow$ Florisil & Muscle & $4.6-6.3$ & $\begin{array}{l}28,47,99,100,153,154,183 ; 5-\mathrm{MeO}-47,6- \\
\mathrm{MeO}-47,2^{\prime}-\mathrm{MeO}-68\end{array}$ & $46-90$ & [94] \\
\hline & $\begin{array}{l}\text { HEX (30), HEX:DCM 7:3 } \\
(30)\end{array}$ & $\begin{array}{l}\mathrm{H}_{2} \mathrm{SO}_{4} \rightarrow \text { anh. } \mathrm{Na}_{2} \mathrm{SO}_{4} \rightarrow \text { acid } \\
\text { silica } \rightarrow \text { activated silica } \rightarrow \mathrm{Na}_{2} \mathrm{SO}_{4} \rightarrow \text { acid } \\
\text { alumina }\end{array}$ & Muscle and liver & - & $\begin{array}{l}3,7,15,17,28,47,49,66,71,77,85,99,100 \\
\text { 119, 126, 138, 153, 154, 156, 183, 184, 191, } \\
\text { 196, 197, 206, 207, 209; 5-MeO-47, 6-MeO- } \\
\text { 47, 4-MeO-49, 2-MeO-68, 5-MeO-99, 5- } \\
\text { MeO-100, 4-MeO-101, 4-MeO-103 }\end{array}$ & $73-117$ & [96] \\
\hline CSE - d-SPE - SPE & $\begin{array}{l}\text { HEX (100), HEX:DCM 1:1 } \\
(150)\end{array}$ & $\begin{array}{l}\text { Acid silica gel } \rightarrow \text { anh. } \\
\mathrm{Na}_{2} \mathrm{SO}_{4} \rightarrow \text { florisil } \rightarrow \text { acid silica } \rightarrow \text { silica }\end{array}$ & Muscle & 2.1 & $28,47,99,100,153,154,183$ & $74-105$ & [93] \\
\hline \multirow[t]{3}{*}{ PLE - SPE } & $\begin{array}{l}\text { HEX (120), HEX:DCM 1:1 } \\
(60)\end{array}$ & $\begin{array}{l}\text { anh. } \mathrm{Na}_{2} \mathrm{SO}_{4} \rightarrow \text { deactivated Florisil } \rightarrow \text { anh. } \\
\mathrm{Na}_{2} \mathrm{SO}_{4} \rightarrow \text { acid silica } \rightarrow \text { anh. } \mathrm{Na}_{2} \mathrm{SO}_{4}\end{array}$ & Whole body & $3.8-6.1$ & $\begin{array}{l}17,28,47,66,85,99,100,153,154,183 \\
197,201,202,203,206,207,208,209\end{array}$ & $57-116$ & [67] \\
\hline & $\begin{array}{l}\text { HEX (70), HEX:DCM 3:2 } \\
(30)\end{array}$ & Acid silica $\rightarrow$ activated neutral alumina & Muscle & $2.1-5.4$ & $28,47,99,100,153,154,183$ & $58-123$ & [81] \\
\hline & - & $\begin{array}{l}\text { anh. } \mathrm{Na}_{2} \mathrm{SO}_{4} \rightarrow \text { silica gel } \rightarrow \text { acid } \\
\text { silica } \rightarrow \text { silica } \rightarrow \text { basic } \\
\text { silica } \rightarrow \text { silica } \rightarrow \text { anh. } \mathrm{Na}_{2} \mathrm{SO}_{4} \rightarrow \text { basic } \\
\text { alumina } \rightarrow \text { anh. } \mathrm{Na}_{2} \mathrm{SO}_{4} \rightarrow \text { carbon }\end{array}$ & Muscle & $1.2-2.8$ & $17,28,47,66,85,99,100,138,153,154,183$ & $75-127$ & [58] \\
\hline \multirow[t]{2}{*}{ PLE - GPC - SPE } & HEX:DCM 1:5 (20) & Silica & Muscle & - & $\begin{array}{l}\text { 28, 30, 33, 47, 75, 85, 99, 153, 154, 155; 6- } \\
\text { MeO-47, 2'-MeO-68 }\end{array}$ & $42-101$ & [101] \\
\hline & $\begin{array}{l}\text { HEX:DCM 1:1 (610), DCM } \\
(20)\end{array}$ & Biobeads S-X3 $\rightarrow$ florisil & Whole body & $3.9-8.6$ & $\begin{array}{l}1,2,3,7,8,10,11,12,13,15,17,25,28,30, \\
3233,35,37,47,49,66,71,75,77,85,99, \\
100,116,118,119,126,138,153,154,155, \\
\text { 166, 181, 183, 190; 2'-MeO-28, 4'-MeO-17, } \\
\text { 6-MeO-47, 6'-MeO-66, 2'-MeO-74, 2'-MeO- } \\
\text { 75; 4'-OH-17, 6-OH-47, 6'-OH-66, 2'-OH } \\
-74,2^{\prime}-\mathrm{OH}-75\end{array}$ & $23-106$ & [86] \\
\hline MAE - SPE & $\begin{array}{l}\text { HEX (300), HEX:DCM 3:2 } \\
(400)\end{array}$ & $\begin{array}{l}\text { Acid silica } \rightarrow \text { anh. } \mathrm{Na}_{2} \mathrm{SO}_{4} \rightarrow \text { acid } \\
\text { silica } \rightarrow \text { basic silica } \rightarrow \text { anh. } \\
\mathrm{Na}_{2} \mathrm{SO}_{4} \rightarrow \text { silanised glass wool }\end{array}$ & Muscle & - & Total PBDEs $(\Sigma 8)$ & $50-100$ & [56] \\
\hline \multirow[t]{2}{*}{ UAE - SPE } & $\begin{array}{l}\text { DCM (90), HEX:DCM 5:1 } \\
\text { (60), HEX:DCM 97:3 (50) }\end{array}$ & $\begin{array}{l}\text { Acid silica } \rightarrow \text { anh. } \mathrm{Na}_{2} \mathrm{SO}_{4} \rightarrow \text { anh. } \\
\mathrm{Na}_{2} \mathrm{SO}_{4} \rightarrow \text { Deactivated silica }\end{array}$ & $\begin{array}{l}\text { Muscle and whole } \\
\text { soft tissue }\end{array}$ & - & $\begin{array}{l}28,47,66,68,85,99,138,153,154,183 ; 2^{\prime}- \\
\text { MeO-68, 6-MeO-47, 3-MeO-47, 5-MeO-47, } \\
\text { 4'-MeO-49, 4-MeO-42, 6'-MeO-99, 5'-MeO- } \\
\text { 99, 6-MeO-85; 3'-OH-28, 4-OH-42, 3-OH- } \\
\text { 47, 4'-OH-49, 5-OH-47, 6-OH-47, 2'-OH-68, } \\
\text { 6-OH-85, 5-OH-99, 6'-OH-99 }\end{array}$ & $73-109$ & [69] \\
\hline & - & $\mathrm{H}_{2} \mathrm{SO}_{4} \rightarrow$ hydromatrix & Muscle & - & $\begin{array}{l}3^{\prime}-\mathrm{OH}-7,3^{\prime}-\mathrm{OH}-28,4^{\prime}-\mathrm{OH}-17,2^{\prime}-\mathrm{OH}-28,3- \\
\mathrm{OH}-47,5-\mathrm{OH}-47,4^{\prime}-\mathrm{OH}-49,6-\mathrm{OH}-47\end{array}$ & - & [51] \\
\hline UAE - SPE - d-SPE - SPE & $\begin{array}{l}\text { HEX (34), Ethyl acetate (8), } \\
\text { ACN (5), HEX:DCM 1:1 (36) }\end{array}$ & $\begin{array}{l}\text { Florisil } \rightarrow \text { acid silica } \rightarrow \mathrm{C}_{18}, \mathrm{Z}- \\
\text { Sep } \rightarrow \text { aminopropyl silica }\end{array}$ & $\begin{array}{l}\text { Muscle and whole } \\
\text { soft tissue }\end{array}$ & $0.1-6.2$ & $28,47,99,100,153,154,183,209$ & $78-144$ & [68] \\
\hline MSPD - UAE - SPE & $\begin{array}{l}\text { HEX (41), HEX:DCM 4:1 } \\
(35)\end{array}$ & $\begin{array}{l}\mathrm{H}_{2} \mathrm{SO}_{4} \rightarrow \text { acid silica } \rightarrow \text { activated } \\
\text { silica } \rightarrow \text { neutral activated alumina }\end{array}$ & Muscle & $3.2-15.2$ & $\begin{array}{l}3,7,15,17,28,47,49,66,71,77,85,99,100 \\
119,126,138,153,154,156,183,184,191 \\
194,195,196,201,202,205,206,207,208 \\
209\end{array}$ & $56-119$ & [57] \\
\hline MSPD & $\begin{array}{l}\text { HEX:DCM 1:1 (0.5), } \\
\text { Acetone (1) }\end{array}$ & Graphene $\rightarrow$ Florisil $\rightarrow$ anh. $\mathrm{Na}_{2} \mathrm{SO}_{4}$ & - & & $\begin{array}{l}\text { 17, 28, 47, 66, 85; 3'-MeO-28, 4-MeO-42, 3- } \\
\text { MeO-47, 5-MeO-47, 6-MeO-47, 4'-MeO-49, } \\
\text { 2'-MeO-68, 6-MeO-85, 5'-MeO-99, 6'-MeO- } \\
\text { 99; 3'-OH-28, 4-OH-42, 3-OH-47, 5-OH-47, } \\
\text { 6-OH-47, 4'OH-49, 2'-OH-68, 6-OH-85, 5'- } \\
\text { OH-99, 6'-OH-99 }\end{array}$ & $23.8-109.9$ & [72] \\
\hline QuEChERs - SPE & $\begin{array}{l}\text { Ethyl acetate (10), HEX (1), } \\
\text { isooctane }(0.5)\end{array}$ & Silica & Muscle & $1.6-14$ & $\begin{array}{l}28,37,47,49,66,77,85,99,100,153,154 \\
183,196,197,203,206,207,209\end{array}$ & $77-107$ & [109] \\
\hline
\end{tabular}




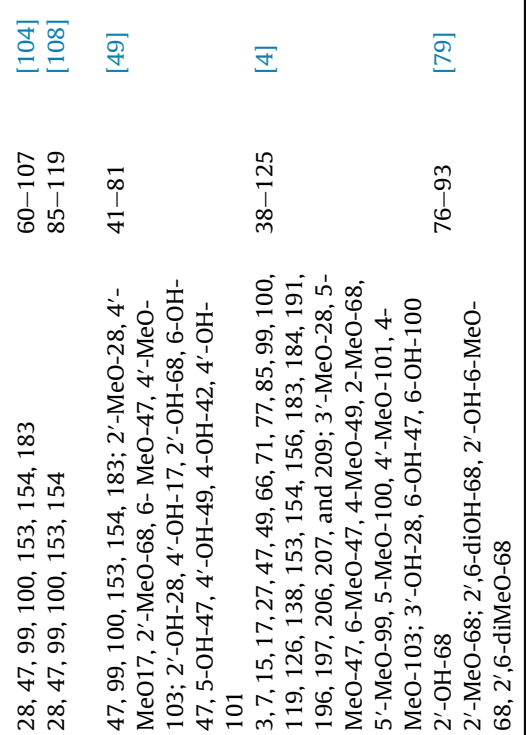

N N fं

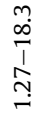

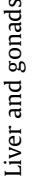

employment of two serially connected GPC columns or GPC followed by further cleanup by SPE to achieve a suitable separation of PBDEs and metabolites from residual lipids and other organohalogenated compounds [5,53-55]. Despite not being able to remove all lipid traces, GPC presents itself as non-destructive and allows handling larger masses of lipids than SPE, while enabling its reuse, which is not possible with SPE.

\subsubsection{Solid-Phase Extraction}

The principle of SPE involves a partitioning of solutes between a liquid (sample matrix or extract) and a solid (sorbent) phase. This classic technique is used in an "off-line" mode and usually starts with sorbent conditioning, followed by sample application, subsequent rinsing and cleaning, and finally desorption and recovery of the analytes to be separated. Nowadays, SPE is more usually regarded as an extraction procedure. Nonetheless, regarding PBDEs and other pollutants, it is often employed as a cleanup step.

Considering sorbent technology, due to the lipid-soluble character of PBDEs and their metabolites, normal-phase inorganic based sorbents, as silica gel, alumina, Florisil ${ }^{\mathbb{R}}$ and silica chemically modified by polar groups such as amino, cyano or diol groups, are the most commonly utilized (Table 5). Generally, the use of acidified silica is enough to provide clean extracts, though several studies have described the use of acidified silica in combination with neutral silica and/or base-modified silica in multi-layer columns for enhanced purification [56-58]. For instance, $5 \mathrm{~g}$ of acidified silica $(40 \%, \mathrm{w} / \mathrm{w})$ is sufficient to purify $0.7 \mathrm{~g}$ of fish lipid samples for PBDEs analysis [59].

SPE usually constitutes a non-destructive (when acid or alkaline treatments are not employed), safe, efficient and reproducible technique. When compared to liquid-liquid extractions, SPE presents numerous advantages, since the former are usually more time-consuming (few hours per sample) and laborious (up to seven extraction steps) [4,48]. Moreover, a strict control of extraction conditions (e.g. temperature, $\mathrm{pH}$ and ionic strength) is required. Hence, SPE shows up as an attractive technique as it considerably provides more autonomy and, at the same time, high recoveries (often greater than $70 \%$, Table 5).

Despite that some studies used miniaturized SPE [60], the majority still requires a huge amount of organic solvents to deliver clean extracts. In fact, around $200 \mathrm{~mL}$ of eluent is used to clean one sample extract, though it may reach up to $700 \mathrm{~mL}$ per sample (Table 5). The most common eluents in SPE of PBDEs in seafood are hexane or hexane:dichloromethane in different proportions, using diverse SPE sorbents, frequently in series. Furthermore, as previously mentioned, SPE cleanup is preceded by an extractive step, generally CSE or PLE (Table 5), so the overall time and solvent consumption should take that into account. If CSE is used, then there is an even greater quantity of residual lipid to be removed, while ready-to-analyse extracts without any additional clean-up step may be obtained by using fat retainer sorbents inside the PLE cell [61-65]. Finally, after SPE cleanup, there is always a need of a concentration step.

It seems that, regardless of matrix fat content, a single SPE step is enough to yield adequate recovery rates [46,56,57,66,67], although more exhaustive cleanup (up to three sequential SPE) can also be employed, even for low fat samples [58,68]. Additionally, different eluents can be sequentially added for fractionation, thus separating PBDEs from MeO-PBDEs and OH-PBDEs, in order to improve chromatographic resolution [69].

\subsection{Integrated extraction and cleanup}

The suitability of integrating a cleanup step into SFE or PLE techniques has been achieved by the use of sorbents in the 
extraction cell which would trap the undesired matrix components $[45,61,62]$.

QuEChERS is a unique analytical methodology, originally designed for extraction/isolation of polar pesticides from fruits and vegetables [70], whose use has already been extended to other pollutants, including PBDEs. This method involves micro scale extraction using acetonitrile, or other organic solvents, followed by addition of magnesium sulphate alone or with other salts, generally sodium chloride. By varying the magnesium sulphate:sodium chloride ratio, it is possible to refine the polarity range to avoid coextraction of interfering substances.

Besides requiring reduced sample sizes and small extraction volumes of less toxic solvents (Table 4), it makes use of common laboratory material and encompasses a small number of steps. As a result, potential sources of systematic and random errors are diminished. Notwithstanding, QuEChERS is a very versatile method that allows working at different pHs and several modifications can be performed at the cleanup step, although this technique cannot easily be automated and the enrichment factor is very poor.

While column-based SPE is often associated with CSE and PLE, d-SPE commonly follows QuEChERS extraction (Table 5). d-SPE is a simple and straightforward cleanup method based on the addition of a sorbent or sorbent mixture into the extract in order to remove the matrix interferences, which is then separated by centrifugation. A standard sorbent mixture used in d-SPE may contain PSA (to remove polar interferences, as organic acids, polar pigments and some sugars), GCB (to remove sterols and pigments such as chlorophyll and carotenoids) and $\mathrm{C}_{18}$ (to remove non-polar interferences, like lipids) [70].

In relation to SPE, d-SPE requires a negligible or inexistence amount of cleanup solvent, thus being a greener approach (Table 5). Moreover, d-SPE ensures larger and more reproducible recoveries of analytes with acidic or basic properties (as OH-PBDEs). Hence, dSPE is by far faster, cost-effective and sustainable, since it uses less sorbent and solvent, smaller amounts of sample and less apparatus and consumables. Plus, it ensures a better interaction between the sorbent and the extract for cleanup [70].

MSPD is a simple and versatile method based on SPE, though it starts with the blend of a solid sample with an appropriate sorbent (usually the ones used in SPE) until a homogeneous dry mixture is obtained. This MSPD blend may then be packed into an empty column (with frits in both edges) for fractionation with a suitable organic eluent.

Labadie and colleagues [57] used ultrasound assisted-MSPD with activated silica gel and sulphuric acid-impregnated silica gel, followed by sulphuric acid digestion and multilayer cartridge cleanup to promote complete lipid removal and elimination of matrix effects during instrumental analysis. High recovery rates (greater than 70\%) were achieved for all twenty-eight PBDEs, including perbrominated BDEs, though high solvent consumption was necessary (more than $100 \mathrm{~mL}$ per $3 \mathrm{~g}$ of freeze-dried sample) [57]. Miniaturization of MSPD using $\mathrm{C}_{18}$ and Florisil as dispersants and acetonitrile:water as eluting solvent resulted in lower sample size $(0.1 \mathrm{~g})$ and low sorbent $(0.4 \mathrm{~g})$ and solvent $(2.6 \mathrm{~mL})$ request, with satisfactory recoveries (between $55 \%$ and $130 \%$ ) for tetra- and penta-BDEs [71]. Liu and co-workers [72] reported high recoveries (higher than 90\%) of PBDEs and MeO-PBDEs using a MSPD method with hexane:dichloromethane $(1: 1, \mathrm{v} / \mathrm{v})$, hexane:acetone $(1: 1, \mathrm{v} / \mathrm{v})$ or acetone as eluents. Among all tested eluents, only acetone led to moderate recoveries of OH-PBDEs (near $80 \%$ ), once strong polarpolar interactions occurred between OH-PBDEs and the sorbents (polar Florisil and CCG) [72]. For extraction and cleanup of all three classes, only $2 \mathrm{~mL}$ of total solvent were required. Still, additional sulphuric acid cleanup was required for fish samples. While the amount of CCG used did not affect PBDEs and MeO-PBDEs recoveries, this variable played a major role in extracting OH-PBDEs (preferably CCG:sample, 1:10), possibly due to the polar moieties of CCG that may induce dispersion of polar components of samples and extraction of polar compounds [72].

MSPD is an excellent alternative to conventional methods since it is a simple, time- (around 15 min per sample) and cost-effective technique that requires a small sample size and low solvent demand, plus it does not require the preparation and maintenance of equipment, and offers the possibility of simultaneously performing extraction and cleanup. Yet, MSPD also presents few drawbacks, since it does not allow automation and may require an additional cleanup step.

Taking into account the extensive variability among available analytical protocols, Table 6 highlights the general performance of extraction and cleanup methods commonly used in PBDEs and their metabolites in seafood.

\section{Instrumental analysis}

Owing to their volatility and polarity, GC is often selected as the analytical separation method for PBDEs and MeO-PBDEs, while LC is commonly chosen for OH-PBDEs analysis. An overview of the main instrumental parameters used in the analysis of PBDEs and their metabolites in seafood studies is presented in Table 7.

\subsection{Injection}

The injection of sample extracts into the GC system is a determinant step for achieving accurate results, especially when target compounds present high boiling points. Automatic sample injection should be employed whenever possible to improve

Table 6

Overall performance of extraction and cleanup methods commonly used in PBDEs and their metabolites in seafood.

\begin{tabular}{|c|c|c|c|c|c|c|c|}
\hline Method & & Efficacy & Organic solvent consumption & Time & Cost & Automation & Operational ease \\
\hline \multirow[t]{5}{*}{ Extraction } & CSE & + & - & - & + & - & ++ \\
\hline & PLE & + & + & + & - & ++ & - \\
\hline & UAE & + & + & + & + & - & - \\
\hline & MAE & + & + & + & - & + & - \\
\hline & SFE & + & ++ & + & - & + & - \\
\hline \multirow[t]{2}{*}{ Cleanup } & GPC & + & - & - & - & + & + \\
\hline & SPE & ++ & - & - & + & + & + \\
\hline Integrated extraction/cleanup & $\begin{array}{l}\text { QuEChERS d-SPE } \\
\text { MSPD }\end{array}$ & $\begin{array}{l}++ \\
+\end{array}$ & $\begin{array}{l}++ \\
+\end{array}$ & $\begin{array}{l}++ \\
+\end{array}$ & $\begin{array}{l}++ \\
++\end{array}$ & $\begin{array}{l}- \\
-\end{array}$ & $\begin{array}{l}++ \\
+\end{array}$ \\
\hline
\end{tabular}

(-), less favourable; $(+)$, favourable; $(++)$, more favourable.

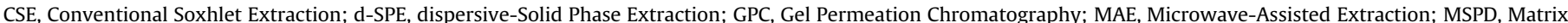

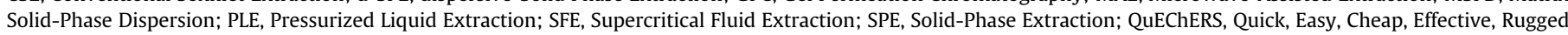
and Safe; UAE, Ultrasound-Assisted Extraction. 
Table 7

Instrumental parameters for PBDEs, MeO- and OH-PBDEs analysis.

\begin{tabular}{|c|c|c|c|c|c|c|c|}
\hline \multirow[t]{2}{*}{ Sample } & \multirow[t]{2}{*}{ Congeners (total) } & \multirow[t]{2}{*}{ GC/LC } & \multirow{2}{*}{$\begin{array}{l}\text { Injection mode } \\
\text { (temperature) }\end{array}$} & \multicolumn{2}{|l|}{ Column system } & \multirow[t]{2}{*}{ Detector } & \multirow[t]{2}{*}{ Ref } \\
\hline & & & & Stationary phase & Dimensions & & \\
\hline $\begin{array}{l}\text { Muscle (bream, carp, gibel carp, } \\
\text { roach, rudd, pike, pikeperch, } \\
\text { tench, wels, white bream) }\end{array}$ & Tri- to hepta-BDEs (7) & GC & Cold splitless $(-)$ & HT-8 & $10 \mathrm{~m} \times 0.10 \mathrm{~mm} \times 0.10 \mu \mathrm{m}$ & ECNI-MS & [83] \\
\hline Muscle (barbel, carp) & Tri- to deca-BDEs (11) & GC & Splitless $\left(275^{\circ} \mathrm{C}\right)$ & HP-5MS & $30 \mathrm{~m} \times 0.25 \mathrm{~mm} \times 0.25 \mu \mathrm{m}$ & NICI-MS & [65] \\
\hline $\begin{array}{l}\text { Muscle and liver (bighead carp, } \\
\text { tilapia) }\end{array}$ & Di- to deca-BDEs (11) & GC & $-\left(290^{\circ} \mathrm{C}\right)$ & DB-5MS & $\begin{array}{l}30 \mathrm{~m} \times 0.25 \mathrm{~mm} \times 0.25 \mu \mathrm{m} \text { (di- to hepta-BDEs) } \\
\text { and } 15 \mathrm{~m} \times 0.25 \mathrm{~mm} \times 0.10 \mu \mathrm{m} \text { (deca-BDE) }\end{array}$ & EI-MS/MS & [95] \\
\hline Muscle (Nile perch, Nile tilapia) & Tri- to deca-BDEs (11) & GC & Splitless (-) & DB-5MS & $30 \mathrm{~m} \times 0.25 \mathrm{~mm} \times 0.10 \mu \mathrm{m}$ & IT-HRMS & [58] \\
\hline $\begin{array}{l}\text { Muscle and whole soft tissue } \\
\text { (salmon, prawn, mussels, tuna) }\end{array}$ & Tri- to deca-BDEs (10) & GC & $\operatorname{PTV}\left(90^{\circ} \mathrm{C}\right)$ & HT-8 & $25 \mathrm{~m} \times 0.22 \mathrm{~mm} \times 0.25 \mu \mathrm{m}$ & EI-MS & [68] \\
\hline Muscle (tilapia) & Tri- to deca-BDEs (9) & GC & $\operatorname{PTV}(-)$ & DB-5MS & $\begin{array}{l}30 \mathrm{~m} \times 0.25 \mathrm{~mm} \times 0.25 \mu \mathrm{m} \text { (di- to hepta-BDEs) } \\
\text { and } 10 \mathrm{~m} \times 0.25 \mathrm{~mm} \times 0.10 \mu \mathrm{m} \text { (deca-BDE) }\end{array}$ & NICI-HRMS & [76] \\
\hline $\begin{array}{l}\text { Muscle and whole soft tissue } \\
\text { (mussel, yellow croaker, softshell } \\
\text { clam) }\end{array}$ & MeO-tetra- to MeO-penta-BDEs (9) & GC & Splitless $\left(280^{\circ} \mathrm{C}\right)$ & DB-5MS & $30 \mathrm{~m} \times 0.25 \mathrm{~mm} \times 0.10 \mu \mathrm{m}$ & EI-MS & [69] \\
\hline Plasma (brown bullhead) & $\begin{array}{l}\text { OH-di- to OH-penta-BDEs (20), } \\
\text { MeO-tri- to MeO-penta-BDEs ( } 20 \text { ) } \\
\text { and tetra- to hepta-BDEs ( } 36 \text { ) }\end{array}$ & GC & $\begin{array}{l}\text { Split/splitless } \\
\left(280^{\circ} \mathrm{C}\right)\end{array}$ & DB-5MS & $\begin{array}{l}60 \mathrm{~m} \times 0.25 \mathrm{~mm} \times 0.25 \mu \mathrm{m}(\text { MeO-PBDEs }) \text { and } \\
15 \mathrm{~m} \times 0.25 \mathrm{~mm} \times 0.10 \mu \mathrm{m}(\text { PBDEs })\end{array}$ & EI-HRMS & [49] \\
\hline Whole body (Pacific herring, trout) & $\begin{array}{l}\text { OH-tri-BDEs (4), MeO-tetra-BDEs } \\
\text { (7) and mono- to deca-BDEs (39) }\end{array}$ & GC & Splitless $\left(300^{\circ} \mathrm{C}\right)$ & $\begin{array}{l}\text { DB5-HT (mono- to hepta-BDEs), } \\
\text { DB5 (octa- to deca-BDEs, OH- } \\
\text { PBDEs and MeO-BDEs) }\end{array}$ & $\begin{array}{l}17 \mathrm{~m} \times 0.25 \mathrm{~mm} \times 0.1 \mu \mathrm{m} \text { (mono- to hepta- } \\
\text { BDEs), } 5 \mathrm{~m} \times 0.25 \mathrm{~mm} \times 0.1 \mu \mathrm{m} \text { (octa- to deca- } \\
\text { BDEs), } 30 \mathrm{~m} \times 0.25 \mathrm{~mm} \times 0.25 \mu \mathrm{m} \text { (OH-PBDEs } \\
\text { and MeO-BDEs) }\end{array}$ & HRMS & [86] \\
\hline $\begin{array}{l}\text { Whole soft tissue (ark shell, blue } \\
\text { mussel, razor clam, short-necked } \\
\text { clam, surf clam) }\end{array}$ & $\begin{array}{l}\text { OH-tri- to OH-hexa-BDEs (5), MeO- } \\
\text { tri- to MeO-hexa-BDEs (14) }\end{array}$ & GC & Splitless $\left(280^{\circ} \mathrm{C}\right)$ & DB-5MS & $30 \mathrm{~m} \times 0.32 \mathrm{~mm} \times 0.25 \mu \mathrm{m}$ & ECNI-MS & [88] \\
\hline $\begin{array}{l}\text { Muscle and whole soft tissue } \\
\text { (mussel, yellow croaker, softshell } \\
\text { clam) }\end{array}$ & OH-tri- to OH-penta-BDEs (5) & LC & - & Dionex $\mathrm{C}_{18}$ & $100 \mathrm{~mm} \times 2.1 \mathrm{~mm} \times 2.2 \mu \mathrm{m}$ & Negative ESI-MS/MS & [69] \\
\hline Whole soft tissue (marine sponge) & Mono- to di-OH-tetra-BDEs (5) & LC & - & Shim-pack FC-ODS & $150 \mathrm{~mm} \times 4.6 \mathrm{~mm} \times 3.0 \mu \mathrm{m}$ & Negative APCI-MS/MS & [79] \\
\hline Muscle (carp) & OH-di- to OH-tetra-BDEs (8) & LC & - & Xbridge $\mathrm{C}_{18}$ & $50 \mathrm{~mm} \times 2.1 \mathrm{~mm} \times 3.5 \mu \mathrm{m}$ & Negative ISP-MS/MS & [51] \\
\hline
\end{tabular}

APCI, atmospheric pressure chemical ionization; BDE, Brominated diphenyl ether; ECNI, electron-capture chemical ionization; EI, electron impact ionization; ESI, electrospray ionization; GC, gas chromatography; ISP, ion-spray ionization; IT, ion trap; HRMS, high resolution mass spectrometry; LC, liquid chromatography; MS, mass spectrometry; NICI, negative ion chemical ionization; PTV, programmable-temperature vaporizer. 
reproducibility and, consequently, overall method's precision. Few injection techniques have been reported concerning PBDEs and MeO-PBDEs extracts, being splitless, pulsed splitless, PTV, and oncolumn injectors, the most common ones.

Since split/splitless injection requires the use of high injection temperatures $\left(250-300^{\circ} \mathrm{C}\right)$, thermal degradation (presence of a hump or an increase in baseline before the peak) of higher brominated BDEs, usually BDE 209, may be observed, thus requiring careful optimization [73].

This thermal degradation and discrimination can also be avoided by the use of on-column injection, since the sample extract is introduced directly into the column $[73,74]$. Nevertheless, this technique demands a more careful extract cleanup than split/ splitless injection to prevent instrumental problems, as increased noise or fast column deterioration.

Since PTV inlets allows a higher injection volume (up to $125 \mu \mathrm{L}$ ) [75], it may help to achieve good LODs, thus this technique is becoming more and more popular in the analysis of PBDEs and their metabolites in seafood samples [68,76,77]. The use of PTV requires a previous optimization (e.g. injection rate, injection temperature, vent flow, temperature rate, transfer temperature, transfer time, injection volume and solvent elimination time) [75] and it may be operated in different modes. For instance, the "temperature programmed pulsed splitless" mode resulted in an overall increased yield of BDE congeners, mainly of highly brominated ones, which present lower vapour pressure [73].

Furthermore, the cleanliness of the liner should not be disregarded, since active sites on dirty liners can also lead to adsorption effects and thermal degradation of target compounds. Such adsorption may be prevented by adding $0.1-0.35 \%(\mathrm{v} / \mathrm{v})$ of dodecane to the sample solution with multibaffled liners to trap the low boiling congeners, as well as changing the liner every 100-200 injections [75].

\subsection{Column system}

Highly brominated PBDEs may also suffer degradation at retention gaps. According to Björklund and colleagues [73], Siltek ${ }^{\circledR}$ deactivated retention gaps may minimize such degradation, since they are not as susceptible to the formation of active silanols as other retention gap deactivation techniques.

The column length and film thickness are two relevant features that affect the retention time of a certain analyte. If a target compound presents low volatility, owing to its high molecular weight (e.g. hepta-to deca-BDEs), then short GC columns (10-15 m) with lower film thickness (less than $0.25 \mu \mathrm{m}$ ) should be employed to reduce residence time and avoid excessive elution temperatures and possible thermal degradation $[28,73,78]$. This fact explains why the determination of BDE-209 is often done separately, using stationary phases of a lower thickness $(0.1 \mu \mathrm{m})$ and/or a shorter column, thus improving its detection (Table 6). Still, columns of 25-50 m length and $0.1-0.3 \mu \mathrm{m}$ thickness are preferable to achieve better peak resolution for all PBDEs and metabolites (Table 6). Even so, BDE-33 co-elution with BDE-28 remains very usual [78].

Mainly non-polar columns, as DB-5MS/HP-5MS, STX-500 and DB-XLB, are used in the chromatographic separation of PBDEs and metabolites (Table 6). However, the latter was found to lead to a complete degradation of BDE-209, while DB-1 showed a better performance [78]. Finally, it is worth mentioning that helium is the reference carrier gas for such analyses.

When OH-PBDEs are separated by LC methods, $\mathrm{C}_{18}$ reversephase columns (50-150 mm) are employed (Table 6), being subjected to either isocratic elution or eluent gradient, both consisting of mixtures of water, ammonium acetate, methanol and acetonitrile $[51,69,72,79]$.

\subsection{Detection}

\subsubsection{Ionization modes}

Nowadays, PBDEs and MeO-PBDEs are usually analysed by GCMS or GC-MS/MS, ion trap or triple quadrupole. Despite recent studies still use GC-ECD [80,81], it is falling into disuse, owing to its limited linear range and lack of selectivity. If GC-ECD is used, the cleanup or chromatographic column will have to separate all other halogenated organic compounds (e.g. PCBs) that may create coelution problems [82].

GC systems using the ECNI have been the most commonly used for PBDEs and MeO-PBDEs detection in seafood samples [68,83,84]. Quantification is usually accomplished using the SIM mode by monitoring the bromide ion isotopes ( $\mathrm{m} / \mathrm{z} 79$ and $\mathrm{m} / \mathrm{z} 81$ ), using the GC-MS chiefly as bromine-selective detector. While ECNI offers better sensitivity to higher brominated PBDEs, EI (also named Electron Impact) displays better sensitivity to lower brominated PBDEs (less than four bromines) [28]. Moreover, isotopically labelled standards $\left({ }^{13} \mathrm{C}\right)$ cannot be used as internal standards in ECNI mode if only the bromide ions are being monitored. Nevertheless, mono fluorinated BDEs are a good alternative when coelution with sample PBDEs does not occur. On the contrary, EI allows the use of ${ }^{13} \mathrm{C}$ labelled internal standards.

Mackintosh and co-workers evaluated the analytical performance of a triple quadrupole mass spectrometer compared to a HR mass spectrometer for the analysis of PBDEs in fish samples [85]. They have verified that IDLs for the GC-MS-MS ranged from $0.04 \mathrm{pg} / \mu \mathrm{L} /$ to $41 \mathrm{pg} / \mu \mathrm{L}$, whereas those for the GC-HR-MS ranged from $5 \mathrm{pg} / \mu \mathrm{L}$ to $85 \mathrm{pg} / \mu \mathrm{L}$. IDLs for MeO-PBDEs and OH-PBDEs may differ in three orders of magnitude, depending on congeners under study, reaching only a few tens of picogram injected into the GC column [86,87].

Despite being increasingly unusual, OH-PBDEs may also be analysed by GC-MS, being subjected to derivatization (e.g. diazomethane or pentafluorobenzoyl chloride/tetra-n-butylammonium hydroxide as derivatizing agents) prior to injection, resulting in the corresponding MeO-PBDEs $[49,88]$. By including a derivatization step, there is an increase of the overall sample analysis time and a possible yield reduction, plus many of such methylating derivatizers are considerably toxic [51]. Hence, LC methods for analysing OH-PBDEs are becoming more popular. Nevertheless, in order to determine derivatized OH-PBDEs by GC-MS, EI should be favoured over ECNI, since the lack of specific masses other than bromine ions (m/z 79 and $\mathrm{m} / \mathrm{z} 81$ ) hampers identification.

Nowadays, LC-MS/MS is a major analytical alternative for the analysis of OH-PBDEs. A number of different ionization modes have been applied in seafood studies, mostly ESI, but also IS and APCI all operating in negative mode [51,69,72,79,89]. The IDLs of OH-PBDEs using the aforementioned ionization techniques in LC-MS varied between 0.01 and $9.1 \mathrm{pg} / \mu \mathrm{L}[51,69,79]$.

\subsubsection{Fragmentation patterns}

As revised by Hites [90], the major fragments formed in EI are the molecular ions that can be used for identification and quantification purposes, followed by other fragment ions (mostly single, but also doubly charged ions due to the loss of $\mathrm{Br}_{2}$ from the molecular ion), often used for confirmation. Hence, selected ion monitoring of the $\left(\mathrm{M}-\mathrm{Br}_{2}\right)^{+}$ion is advisable for PBDEs determination. However, BDE-77 presents a singular mass spectrum, since it shows almost no $\left(\mathrm{M}-\mathrm{Br}_{2}\right)^{+}$ion [90].

On the other hand, ECNI spectra of PBDEs with seven or less bromines are mainly represented by $\mathrm{Br}^{-}$and $\mathrm{HBr}^{2-}$ (in a lesser extent), while higher brominated BDEs also reveal tetra- or pentabromophenoxide ions, due to cleavage of the phenyl-ether linkage, since the negative charge is likely located on the oxygen atom 
[90]. Therefore, $\mathrm{m} / \mathrm{z} 79$ and 81 are preferred for PBDEs with seven or less bromides, while phenoxide ions are analytically useful for quantitation of the octa- to deca-BDEs (excepting BDE-206 whose

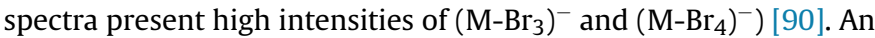
analytical method may also take profit of ion source temperature impact on the abundance of $\mathrm{Br}^{-}$in the ECNI spectra, since higher temperatures increase sensitivity [90].

As regards to $\mathrm{MeO}-\mathrm{PBDEs}$, ECNI spectra are also dominated by $\mathrm{Br}^{-}$and $\mathrm{HBr}_{2}^{-}$, which as already mentioned before, hinders compound identification. Still, the abundance of $\mathrm{HBr}_{2}^{-}$ions are slightly higher for meta- and para-substituted, while ortho-substituted MeO-PBDEs have a variable abundance of $\mathrm{m} / \mathrm{z}$ 186/8 and 266 [90].

Contrariwise, EI spectra allow the distinction between ortho, meta or para position of methoxyl in relation to the phenyl-ether linkage. Albeit $\left(\mathrm{M}-\mathrm{Br}_{2}\right)^{+}$ion is prominent in PBDE spectra, for MeO-PBDEs such is only verified for meta-substituted ones, which also significantly produce $\left(\mathrm{M}-\mathrm{CH}_{3} \mathrm{Br}_{2}\right)^{+}$ions [90]. Concerning orthosubstituted congeners, the $\mathrm{M}-\mathrm{CH}_{3} \mathrm{Br}$ ion is highly abundant, likely due to the production of a stable brominated dibenzo-para-dioxin ion [90]. As for para-substituted congeners, $\mathrm{M}-\mathrm{CH}_{3}$ ions are consistently present [90].

For non-derivatized OH-PBDEs, ionized by IS operating in negative mode, different mass spectra were observed according to the position of hydroxyl in relation to the phenyl-ether bond [51]. For instance, for ortho-hydroxylated BDEs only the formation of $\mathrm{Br}^{-}$was verified. On the contrary, meta-substituted OH-PBDEs suffered bromine abstraction, cleavage of the ether bond producing bromophenoxide ions and resulted in the formation of both $\mathrm{Br}^{-}$isotopes. Finally, para-substituted OH-PBDEs mass spectra represented the formation of bromobenzoquinone anions and both $\mathrm{Br}^{-}$isotopes.

Few authors have performed quantitative analysis of OH-PBDEs by LC-ESI-MS [69,72]. For ortho-substituted OH-PBDEs, only $\mathrm{m} / \mathrm{z} 79$ and $\mathrm{m} / \mathrm{z} 81$ were used for quantification purposes, while for metahydroxylated BDEs, $\mathrm{Br}^{-}$and $(\mathrm{M}-\mathrm{Br})^{-}$ions were favoured. Concerning para-substituted OH-PBDEs, a loss of $\mathrm{m} / \mathrm{z} 265$ occurred (likely corresponding to $\left[\mathrm{C}_{6} \mathrm{H}_{2} \mathrm{Br}_{2} \mathrm{O}_{2}\right]^{-}$), that was selected for quantification.

\section{Quality assurance/Quality control}

\subsection{Quality assurance}

The sample under study may suffer contamination throughout the analytical procedure, mostly by solvents and reagents used, but it can also occur even before the sample arrives to the laboratory, i.e. during sampling, sample handling and pre-treatment. Such can happen owing to the environment, packing materials or instruments used during sample preparation. It shall not be forgotten that PBDEs have a widespread existence, so they are very likely present in materials and equipment used for sample handling and treatment.

No plastic materials, except polyethylene or polytetrafluorethene, should be used for sampling, due to the possible exchange of contaminants from or into the container material [28]. Seafood dissection should be performed in a clean bench, always avoiding contact with potentially PBDE-containing materials and products [28]. It should be undertaken by trained personnel wearing clean gloves, and using clean stainless steel knives, scalpels, and homogenizers [28]. Afterwards, the working bench, all tools and equipment used for sample preparation should be washed with standard laboratory detergent, as Decon ${ }^{\circledR} 90$, and rinsed thoroughly with deionized water followed by a solvent [28].

Finally, processed samples should be stored in clear and indelible labelled solvent-washed aluminium cans or glass jars, preferably prebaked at $450^{\circ} \mathrm{C}$ [28].

\subsection{Quality control}

Nowadays, there any many companies offering high-purity calibration and internal standards $\left({ }^{13} \mathrm{C},{ }^{2} \mathrm{H}\right.$ or fluorinated analogues) for PBDEs and MeO-PBDEs, but the same does not apply for OH-PBDEs. Still, isotope dilution analysis is particularly recommended in trace determinations since intermediate manipulations of the sample (from extraction to chromatographic separation) as well as any changes in instrumental sensitivity will not affect the final result as any aliquot of the isotope diluted sample will show the same isotope composition [91].

Howsoever, a multilevel calibration curve with at least five points should be employed for quantification. Calibration standards prepared from high-purity standard solutions should be stored in the dark and preferably in amber glass gas tight flasks, to prevent photodegradation and solvent evaporation. Also, the use of adequate internal standards as recovery and syringe standards is advisable.

A procedural blank should also be prepared to help defining the method and instrumental limits of detection and quantification. According to Webster and colleagues [28], achievable limits of determination based on a $10 \mathrm{~g} \mathrm{WW}$ biota sample for each individual component, are as follows: 1) GC-ECNI-MS: $0.05 \mathrm{ng} / \mathrm{g}$ for tri- to hepta-BDEs and $0.50 \mathrm{ng} / \mathrm{g}$ for BDE-209; 2) GC-EI-MS: $0.5 \mathrm{ng} / \mathrm{g}$; and 3) High-resolution GC-MS: $0.02 \mathrm{pg} / \mathrm{g}$ for tri- to hepta-BDEs and $0.5 \mathrm{pg} / \mathrm{g}$ for BDE-209.

The analyst should also evaluate the method's precision and repeatability. The accuracy of an analytical method should fall between $70 \%$ and $120 \%$ recovery rate, and it may be evaluated either by sample fortification, LRM or CRM analysis [28]. Both LRM and CRM should be of the same matrix type as the samples under study. Few CRMs certified for PBDEs in seafood are available at the NIST, as "SRM 1947 - Lake Michigan Fish Tissue".

From time to time, it is recommended that the laboratory participate in interlaboratory exercises, as those from the QUASIMEME programme, aiming to provide an independent evaluation on a certain analytical method's performance.

\section{Conclusions}

PBDEs constitute a relevant class of additive BFRs from an economical and environmental perspective, mainly due to its proven toxicity and bioaccumulation ability. Likely, as an attempt to provide a solid knowledge on their occurrence in seafood (the major exposure pathway for humans), to enable these contaminants to become duly regulated, a multiplicity of research initiatives has focused such assessment. For this purpose, alternative extraction techniques, such as PLE or SFE, have been developed to replace lingering CSE. These new extraction techniques offer the advantages of significantly reducing the organic solvent consumption, favouring automation and allowing the introduction of an on-line cleanup step. However, due to their high investment costs, CSE still remains the most widely used technique for PBDEs extraction from seafood samples.

In general, extraction techniques are followed by GPC and/or SPE for purification and fractionation of extracts, which undoubtedly provide good analyte recoveries, but often require high extraction volumes. Emerging techniques such QuEChERS or UAE, followed by d-SPE, have only been employed in a limited number of studies so far. Nevertheless, their promising results show that their application may likely expand in the near future. Encouraging the use of sustainable analytical methods not only reduces waste generation in the laboratory, but it also leads to a global reduction in environmental pressure with subsequent health improvements. 
Only with adequate analytical tools and data from wide and regular monitoring surveys will enable to provide the necessary information for implementing effective food safety regulation.

\section{Notes}

The authors declare no competing financial interest.

\section{Acknowledgments}

Rebeca Cruz, Sara C. Cunha and Susana Casal thanks REQUIMTE, FCT (Fundação para a Ciência e a Tecnologia) and FEDER through the project UID/QUI/50006/2013 - POCI/01/0145/FEDER/007265 with financial support from FCT/MEC through national funds and co-financed by FEDER, under the Partnership Agreement PT2020. R. Cruz also thanks to REQUIMTE FCT for the PhD grant - SFRH/BD/ 101945/2014. António Marques and Sara C. Cunha acknowledge FCT for the IF2014 and IF/01616/2015 contracts, respectively.

\section{References}

[1] P. Kiliaris, C.D. Papaspyrides, Chapter 1-Polymers on Fire, Polymer Green Flame Retardants, Elsevier, Amsterdam, 2014, pp. 1-43.

[2] C.A. de Wit, M. Alaee, D.C.G. Muir, Levels and trends of brominated flame retardants in the Arctic, Chemosphere 64 (2006) 209-233.

[3] E. Dahlgren, D. Lindqvist, H. Dahlgren, L. Asplund, K. Lehtilä, Trophic transfer of naturally produced brominated aromatic compounds in a Baltic sea food chain, Chemosphere 144 (2016) 1597-1604.

[4] U.-J. Kim, H. Jo, I.-S. Lee, G.-J. Joo, J.-E. Oh, Investigation of bioaccumulation and biotransformation of polybrominated diphenyl ethers, hydroxylated and methoxylated derivatives in varying trophic level freshwater fishes, Chemosphere 137 (2015) 108-114.

[5] K. Law, T. Halldorson, R. Danell, G. Stern, S. Gewurtz, M. Alaee, C. Marvin, M. Whittle, G. Tomy, Bioaccumulation and trophic transfer of some brominated flame retardants in a Lake Winnipeg (Canada) food web, Environ. Toxicol. Chem. 25 (2006) 2177-2186.

[6] V. Linares, M. Bellés, J.L. Domingo, Human exposure to PBDE and critical evaluation of health hazards, Archives Toxicol. 89 (2015) 335-356.

[7] SCPOP, Stockholm Convention On Persistent Organic Pollutants, in: U. Nations (Editor), Adoption of Amendments to Annexes A, B and C, 2009. Geneva.

[8] D. 2002/95/EC, Directive 2002/95/EC on the Restriction of the Use of Certain Hazardous Substances in Electrical and Electronic Equipment, in: E.P.a.t.C.o.t.E. Union (Editor), Official Journal of the European Union, 2003.

[9] C.R.E.N. 552/2009, Commission Regulation (EC) No 552/2009 amending Regulation (EC) No 1907/2006 of the European Parliament and of the Council on the Registration, Evaluation, Authorisation and Restriction of Chemicals (REACH) as regards Annex XVII, in: C.O.T.E. Communities (Editor), Official Journal of the European Union Brussels, 2009.

[10] SNUR, in: E.P. Agency (Editor), Significant New Use Rule and Test Rule Certain Polybrominated Diphenylethers, Environmental Protection Agency, 2012.

[11] SNUR, in: E.P. Agency (Editor), Significant New Use Rule Certain Polybrominated Diphenylethers, Environmental Protection Agency, 2006.

[12] S.T, in: M.o.I.I.o.t.P.s.R.o. China (Editor), Requirements for Concentration Limits for Certain Hazardous Substances in Electronic Information Products, 2006. SJ/T 11363 - 2006, 2006.

[13] G.o. Canada, Polybrominated Diphenyl Ethers Regulations, 2008.

[14] S.B. Wiseman, Y. Wan, H. Chang, X. Zhang M. Hecker, P.D. Jones, J.P. Giesy, Polybrominated diphenyl ethers and their hydroxylated/methoxylated analogs: environmental sources, metabolic relationships, and relative toxicities, Mar. Pollut. Bull. 63 (2011) 179-188.

[15] K. Ballschmiter, A. Mennel, J. Buyten, Long chain alkyl-polysiloxanes as nonpolar stationary phases in capillary gas chromatography, Fresenius' J. Anal. Chem. 346 (1993) 396-402.

[16] G. Marsh, R. Stenutz, Å. Bergman, Synthesis of hydroxylated and methoxylated polybrominated diphenyl ethers - natural products and potential polybrominated diphenyl ether metabolites, Eur. J. Org. Chem. 2003 (2003) $2566-2576$.

[17] A. Malmvärn, G. Marsh, L. Kautsky, M. Athanasiadou, Å. Bergman, L. Asplund, Hydroxylated and methoxylated brominated diphenyl ethers in the red algae Ceramium tenuicorne and blue mussels from the Baltic sea, Environ. Sci. Technol. 39 (2005) 2990-2997.

[18] C.M. Reddy, L. Xu, T.I. Eglinton, J.P. Boon, D.J. Faulkner, Radiocarbon content of synthetic and natural semi-volatile halogenated organic compounds, Environ. Pollut. 120 (2002) 163-168.
[19] J.L. Domingo, Polybrominated diphenyl ethers in food and human dietary exposure: a review of the recent scientific literature, Food Chem. Toxicol. 50 (2012) 238-249.

[20] EPA, in: U.E.P. Agency (Editor), Integrated Risk Information System Assessments, 2008.

[21] S. Jacobs, I. Sioen, Z. Pieniak, S. De Henauw, A.L. Maulvault, M. Reuver, G. Fait, G. Cano-Sancho, W. Verbeke, Consumers' health risk-benefit perception of seafood and attitude toward the marine environment: insights from five European countries, Environ. Res. 143 (Part B) (2015) 11-19.

[22] G. Vandermeersch, H.M. Lourenço, D. Alvarez-Muñoz, S. Cunha, J. Diogène, G. Cano-Sancho, J.J. Sloth, C. Kwadijk, D. Barcelo, W. Allegaert, K. Bekaert, J.O. Fernandes, A. Marques, J. Robbens, Environmental contaminants of emerging concern in seafood - European database on contaminant levels, Environ. Res. 143 (Part B) (2015) 29-45.

[23] R. Cruz, S.C. Cunha, S. Casal, Brominated flame retardants and seafood safety: a review, Environ. Int. 77 (2015) 116-131.

[24] K.R. Echols, P.H. Peterman, J.E. Hinck, C.E. Orazio, Polybrominated diphenyl ether metabolism in field collected fish from the Gila River, Arizona, USA levels, possible sources, and patterns, Chemosphere 90 (2013) 20-27.

[25] V. Berg, M.A. Zerihun, A. Jørgensen, E. Lie, O.B. Dale, J.U. Skaare, J.L. Lyche, High prevalence of infections and pathological changes in burbot (Lota lota) from a polluted lake (Lake Mjøsa, Norway), Chemosphere 90 (2013) $1711-1718$.

[26] ECsafeSEAFOOD, Presence and Levels of Priority Contaminants in Seafood, Priority Environmental Contaminants in Seafood: Safety Assessment, Impact and Public Perception, 2016.

[27] K. Löfstrand, X. Liu, D. Lindqvist, S. Jensen, L. Asplund, Seasonal variations of hydroxylated and methoxylated brominated diphenyl ethers in blue mussels from the Baltic Sea, Chemosphere 84 (2011) 527-532.

[28] L. Webster, J. Tronczynski, P. Bersuder, K. Vorkamp, P. Lepom, Determination of Polybrominated Diphenyl Ethers (PBDEs) in Sediment and Biota, ICES Techniques in Marine Environmental Sciences, Denmark, 2010.

[29] D. Teclechiel, Synthesis and Characterization of Highly Polybrominated Diphenyl Ethers, Department of Environmental Chemistry, Stockholm University, Stockholm, 2008, p. 73

[30] B. Admire, B. Lian, S.H. Yalkowsky, Estimating the physicochemical properties of polyhalogenated aromatic and aliphatic compounds using UPPER Part 1. Boiling point and melting point, Chemosphere 119 (2015) $1436-1440$

[31] C. Yue, L.Y. Li, Filling the gap: estimating physicochemical properties of the full array of polybrominated diphenyl ethers (PBDEs), Environ. Pollut. 180 (2013) 312-323.

[32] E. Braekevelt, S.A. Tittlemier, G.T. Tomy, Direct measurement of octanol-water partition coefficients of some environmentally relevant brominated diphenyl ether congeners, Chemosphere 51 (2003) 563-567.

[33] T. Harner, M. Shoeib, Measurements of Octanol-Air partition coefficients (KOA) for polybrominated diphenyl ethers (PBDEs): predicting partitioning in the environment, J. Chem. Eng. Data 47 (2002) 228-232.

[34] T. Gouin, T. Harner, Modelling the environmental fate of the polybrominated diphenyl ethers, Environ. Int. 29 (2003) 717-724.

[35] Y. Yu, W. Yang, Z. Gao, M.H.W. Lam, X. Liu, L. Wang, H. Yu, RP-HPLC measurement and quantitative structure-property relationship analysis of the noctanol-water partitioning coefficients of selected metabolites of polybrominated diphenyl ethers, Environ. Chem. 5 (2008) 332-339.

[36] H. Zhao, Q. Xie, F. Tan, J. Chen, X. Quan, B. Qu, X. Zhang, X. Li, Determination and prediction of octanol-air partition coefficients of hydroxylated and methoxylated polybrominated diphenyl ethers, Chemosphere 80 (2010) 660-664.

[37] S. Rayne, K. Forest, pKa values of the monohydroxylated polychlorinated biphenyls (OH-PCBs), polybrominated biphenyls (OH-PBBs), polychlorinated diphenyl ethers (OH-PCDEs), and polybrominated diphenyl ethers $(\mathrm{OH}-$ PBDEs), J. Environ. Sci. Health Part A 45 (2010) 1322-1346.

[38] Y. Pan, D.C.W. Tsang, Y. Wang, Y. Li, X. Yang, The photodegradation of polybrominated diphenyl ethers (PBDEs) in various environmental matrices: kinetics and mechanisms, Chem. Eng. J. 297 (2016) 74-96.

[39] C.R.E.N. 252/2012, Commission regulation (EU) No 252/2012 of 21 March 2012 laying down methods of sampling and analysis for the official contro of levels of dioxins, dioxinlike PCBs and non-dioxin-like PCBs in certain foodstuffs and repealing Regulation (EC) No 1883/2006, in: E. Commission (Editor), Official Journal of the European Union Brussels, 2012.

[40] P.T. Anastas, J.C. Warner, Green Chemistry: Theory and Practice, Oxford University Press, 2000

[41] M.K.-Y. Li, N.-Y. Lei, C. Gong, Y. Yu, K.-H. Lam, M.H.-W. Lam, H. Yu, P.K.S. Lam, An organically modified silicate molecularly imprinted solid-phase microextraction device for the determination of polybrominated diphenyl ethers, Anal. Chim. Acta 633 (2009) 197-203.

[42] G. Ren, Z. Wang, Z. Yu, Y. Wang, S. Ma, M. Wu, G. Sheng, J. Fu, Primary investigation on contamination pattern of legacy and emerging halogenated organic pollution in freshwater fish from Liaohe River, Northeast China, Environ. Pollut. 172 (2013) 94-99.

[43] A.C. Dirtu, A. Covaci, A.C. Dirtu, M. Abdallah, Advances in the sample preparation of brominated flame retardants and other brominated compounds, TrAC Trends Anal. Chem. 43 (2013) 189-203.

[44] M. Rostagno, J. Prado, Natural Product Extraction: Principles and Applications, RSC Green Chemistry, Cambridge, UK, 2013. 
[45] R. Rodil, A.M. Carro, R.A. Lorenzo, R. Cela Torrijos, Selective extraction of trace levels of polychlorinated and polybrominated contaminants by supercritical fluid-solid-phase microextraction and determination by gas chromatography/mass spectrometry. Application to aquaculture fish feed and cultured marine species, Anal. Chem. 77 (2005) 2259-2265.

[46] K.C. Cheung, J.S. Zheng, H.M. Leung, M.H. Wong, Exposure to polybrominated diphenyl ethers associated with consumption of marine and freshwater fish in Hong Kong, Chemosphere 70 (2008) 1707-1720.

[47] J. Xu, Z. Gao, Q. Xian, H. Yu, J. Feng, Levels and distribution of polybrominated diphenyl ethers (PBDEs) in the freshwater environment surrounding a PBDE manufacturing plant in China, Environ. Pollut. 157 (2009) 1911-1916.

[48] Y.-H. Zeng, X.-J. Luo, X.-B. Zheng, B. Tang, J.-P. Wu, B.-X. Mai, Species-specific bioaccumulation of halogenated organic pollutants and their metabolites in fish serum from an e-waste site, South China, Archives Environ. Contam. Toxicol. 67 (2014) 348-357.

[49] A. De la Torre, G. Pacepavicius, M.A. Martínez, C. Darling, D. Muir, J. Sherry, M. McMaster, M. Alaee, Polybrominated diphenyl ethers and their methoxylated and hydroxylated analogs in Brown Bullhead (Ameiurus nebulosus) plasma from Lake Ontario, Chemosphere 90 (2013) 1644-1651.

[50] M. Bratberg, P.A. Olsvik, R.B. Edvardsen, H.K. Brekken, R. Vadla, S. Meier Effects of oil pollution and persistent organic pollutants (POPs) on glycerophospholipids in liver and brain of male Atlantic cod (Gadus morhua) Chemosphere 90 (2013) 2157-2171.

[51] S. Mas, O. Jáuregui, F. Rubio, A. de Juan, R. Tauler, S. Lacorte, Comprehensive liquid chromatography-ion-spray tandem mass spectrometry method for the identification and quantification of eight hydroxylated brominated diphenyl ethers in environmental matrices, J. Mass Spectrom. 42 (2007) 890-899.

[52] M. Brebu, T. Bhaskar, A. Muto, Y. Sakata, Alkaline hydrothermal treatment of brominated high impact polystyrene (HIPS-Br) for bromine and brominefree plastic recovery, Chemosphere 64 (2006) 1021-1025.

[53] B.C. Kelly, M.G. Ikonomou, J.D. Blair, F.A.P.C. Gobas, Bioaccumulation behaviour of polybrominated diphenyl ethers (PBDEs) in a Canadian Arctic marine food web, Sci. Total Environ. 401 (2008) 60-72.

[54] Q. Hao, Y.-X. Sun, X.-R. Xu, Z.-W. Yao, Y.-S. Wang, Z.-W. Zhang, X.-J. Luo, B.$\mathrm{X}$. Mai, Occurrence of persistent organic pollutants in marine fish from the Natuna Island, South China Sea, Mar. Pollut. Bull. 85 (2014) 274-279.

[55] S. Takahashi, T. Oshihoi, K. Ramu, T. Isobe, K. Ohmori, T. Kubodera, S. Tanabe, Organohalogen compounds in deep-sea fishes from the western North Pacific, off-Tohoku, Japan: contamination status and bioaccumulation profiles, Mar. Pollut. Bull. 60 (2010) 187-196.

[56] M. Rose, A. Fernandes, D. Mortimer, C. Baskaran, Contamination of fish in UK fresh water systems: risk assessment for human consumption, Chemosphere 122 (2015) 183-189.

[57] P. Labadie, F. Alliot, C. Bourges, A. Desportes, M. Chevreuil, Determination of polybrominated diphenyl ethers in fish tissues by matrix solid-phase dispersion and gas chromatography coupled to triple quadrupole mass spectrometry: case study on European eel (Anguilla anguilla) from Mediterranean coastal lagoons, Anal. Chim. Acta 675 (2010) 97-105.

[58] P. Ssebugere, M. Sillanpää, P. Wang, Y. Li, B.T. Kiremire, G.N. Kasozi, C. Zhu, D. Ren, H. Shang, Q. Zhang, G. Jiang, Polychlorinated dibenzo-p-dioxins, polychlorinated dibenzofurans and polybrominated diphenyl ethers in sediments and fish species from the Murchison Bay of Lake Victoria, Uganda, Sci. Total Environ. 500-501 (2014) 1-10.

[59] M.N. Jacobs, A. Covaci, A. Gheorghe, P. Schepens, Time trend investigation of PCBs, PBDEs, and organochlorine pesticides in selected $n-3$ polyunsaturated fatty acid rich dietary fish oil and vegetable oil supplements; nutritional relevance for human essential n-3 fatty acid requirements, J. Agric. Food Chem. 52 (2004) 1780-1788.

[60] A.R. Fontana, A. Camargo, L.D. Martinez, J.C. Altamirano, Dispersive solidphase extraction as a simplified clean-up technique for biological sample extracts. Determination of polybrominated diphenyl ethers by gas chromatography-tandem mass spectrometry, J. Chromatogr. A 1218 (2011) 2490-2496.

[61] Y.P. Liu, J.G. Li, Y.F. Zhao, Y.N. Wu, L.Y. Zhu, Rapid determination of polybrominated diphenyl ethers (PBDEs) in fish using selective pressurized liquid extraction (SPLE) combined with automated online gel permeation chromatography-gas chromatography mass spectrometry (GPC-GC/MS), Food Addit. Contam. Part A 26 (2009) 1180-1184.

[62] S. Losada, F.J. Santos, M.T. Galceran, Selective pressurized liquid extraction of polybrominated diphenyl ethers in fish, Talanta 80 (2009) 839-845.

[63] N. Tapie, K.L. Menach, S. Pasquaud, P. Elie, M.H. Devier, H. Budzinski, PBDE and PCB contamination of eels from the Gironde estuary: from glass eels to silver eels, Chemosphere 83 (2011) 175-185.

[64] J. Koistinen, H. Kiviranta, P. Ruokojärvi, R. Parmanne, M. Verta, A. Hallikainen, T. Vartiainen, Organohalogen pollutants in herring from the northern Baltic Sea: concentrations, congener profiles and explanatory factors, Environ. Pollut. 154 (2008) 172-183.

[65] E. Eljarrat, A. Labandeira, G. Marsh, D. Raldúa, D. Barceló, Decabrominated diphenyl ether in river fish and sediment samples collected downstream an industrial park, Chemosphere 69 (2007) 1278-1286.

[66] R.-X. Sun, X.-J. Luo, X.-X. Tan, B. Tang, Z.-R. Li, B.-X. Mai, An eight year (2005-2013) temporal trend of halogenated organic pollutants in fish from the Pearl River Estuary, South China, Mar. Pollut. Bull. 93 (2015) $61-67$.
[67] M. Gassel, S. Harwani, J.-S. Park, A. Jahn, Detection of nonylphenol and persistent organic pollutants in fish from the North Pacific Central Gyre, Mar. Pollut. Bull. 73 (2013) 231-242.

[68] F. Xu, Á. García-Bermejo, G. Malarvannan, B. Gómara, H. Neels, A. Covaci, Multi-contaminant analysis of organophosphate and halogenated flame retardants in food matrices using ultrasonication and vacuum assisted extraction, multi-stage cleanup and gas chromatography-mass spectrometry, J. Chromatogr. A 1401 (2015) 33-41.

69] J. Sun, J. Liu, Q. Liu, G. Qu, T. Ruan, G. Jiang, Sample preparation method for the speciation of polybrominated diphenyl ethers and their methoxylated and hydroxylated analogues in diverse environmental matrices, Talanta 88 (2012) 669-676.

[70] M. Anastassiades, S.J. Lehotay, D. Stajnbaher, F.J. Schenck, Fast and easy multiresidue method employing acetonitrile extraction/partitioning and "dispersive solid-phase extraction" for the determination of pesticide residues in produce, J. AOAC Int. 86 (2003) 412-431.

[71] Y. Moliner-Martinez, P. Campíns-Falcó, C. Molins-Legua, L. Segovia-Martínez, A. Seco-Torrecillas, Miniaturized matrix solid phase dispersion procedure and solid phase microextraction for the analysis of organochlorinated pesticides and polybrominated diphenylethers in biota samples by gas chromatography electron capture detection, J. Chromatogr. A 1216 (2009) $6741-6745$.

[72] O. Liu, J. Shi, J. Sun, T. Wang, L. Zeng, N. Zhu, G. Jiang, Graphene-assisted matrix solid-phase dispersion for extraction of polybrominated diphenyl ethers and their methoxylated and hydroxylated analogs from environmental samples, Anal. Chim. Acta 708 (2011) 61-68.

[73] J. Björklund, P. Tollbäck, C. Hiärne, E. Dyremark, C. Östman, Influence of the injection technique and the column system on gas chromatographic determination of polybrominated diphenyl ethers, J. Chromatogr. A 1041 (2004) 201-210.

[74] A. Binelli, C. Roscioli, L. Guzzella, Improvements in the analysis of decabromodiphenyl ether using on-column injection and electron-capture detection, J. Chromatogr. A 1136 (2006) 243-247.

[75] P. Tollbäck, J. Björklund, C. Östman, Large-volume programmed-temperature vaporiser injection for fast gas chromatography with electron capture and mass spectrometric detection of polybrominated diphenyl ethers, J. Chromatogr. A 991 (2003) 241-253.

[76] A. Polder, M.B. Müller, J.L. Lyche, R.H. Mdegela, H.E. Nonga, F.P. Mabiki, T.J. Mbise, J.U. Skaare, M. Sandvik, E. Skjerve, E. Lie, Levels and patterns of persistent organic pollutants (POPs) in tilapia (Oreochromis sp.) from four different lakes in Tanzania: geographical differences and implications for human health, Sci. Total Environ. 488-489 (2014) 252-260.

[77] E. Hoh, S.J. Lehotay, K.C. Pangallo, K. Mastovska, H.L. Ngo, C.M. Reddy, W. Vetter, Simultaneous quantitation of multiple classes of organohalogen compounds in fish oils with direct sample introduction comprehensive twodimensional gas chromatography and time-of-flight mass spectrometry, J. Agric. Food Chem. 57 (2009) 2653-2660.

[78] P. Korytár, A. Covaci, J de Boer, A. Gelbin, U.A.T, Brinkman, Retention-time database of 126 polybrominated diphenyl ether congeners and two Bromkal technical mixtures on seven capillary gas chromatographic columns, J. Chromatogr. A 1065 (2005) 239-249.

[79] Y. Kato, S. Okada, K. Atobe, T. Endo, K. Haraguchi, Selective determination of mono- and dihydroxylated analogs of polybrominated diphenyl ethers in marine sponges by liquid-chromatography tandem mass spectrometry, Anal. Bioanal. Chem. 404 (2012) 197-206.

[80] R. Turja, N. Höher, P. Snoeijs, J. Baršienè, L. Butrimavičienè, T. Kuznetsova, S.V. Kholodkevich, M.H. Devier, H. Budzinski, K.K. Lehtonen, A multibiomarker approach to the assessment of pollution impacts in two Baltic Sea coastal areas in Sweden using caged mussels (Mytilus trossulus), Sci. Total Environ. 473-474 (2014) 398-409.

[81] T. Xu, I.K. Cho, D. Wang, F.M. Rubio, W.L. Shelver, A.M.E. Gasc, J. Li, Q.X. Li, Suitability of a magnetic particle immunoassay for the analysis of PBDEs in Hawaiian euryhaline fish and crabs in comparison with gas chromatography/ electron capture detection-ion trap mass spectrometry, Environ. Pollut. 157 (2009) 417-422.

[82] M. Alaee, S. Backus, C. Cannon, Potential interference of PBDEs in the determination of PCBs and other organochlorine contaminants using electron capture detection, J. Sep. Sci. 24 (2001) 465-469.

[83] A. Covaci, A. Gheorghe, O. Hulea, P. Schepens, Levels and distribution of organochlorine pesticides, polychlorinated biphenyls and polybrominated diphenyl ethers in sediments and biota from the Danube Delta, Romania, Environ. Pollut. 140 (2006) 136-149.

[84] D.A. Stephansen, T.C. Svendsen, K. Vorkamp, J.-O. Frier, Changes in patterns of persistent halogenated compounds through a pelagic food web in the Baltic Sea, Mar. Environ. Res. 73 (2012) 17-24.

[85] S.A. Mackintosh, A. Pérez-Fuentetaja, L R. Zimmerman, G. Pacepavicius, M. Clapsadl, M. Alaee, D.S. Aga, Analytical performance of a triple quadrupole mass spectrometer compared to a high resolution mass spectrometer for the analysis of polybrominated diphenyl ethers in fish, Anal. Chim. Acta 747 (2012) 67-75.

[86] S. Lacorte, M.G. Ikonomou, M. Fischer, A comprehensive gas chromatography coupled to high resolution mass spectrometry based method for the determination of polybrominated diphenyl ethers and their hydroxylated and methoxylated metabolites in environmental samples, J. Chromatogr. A 1217 (2010) 337-347. 
[87] Y. Qiu, A. Strid, A. Bignert, Z. Zhu, J. Zhao, M. Athanasiadou, I. Athanassiadis, A. Bergman, Chlorinated and brominated organic contaminants in fish from Shanghai markets: a case study of human exposure, Chemosphere 89 (2012) 458-466.

[88] X. Liu, Y. Jiao, C. Lin, K. Sun, Y. Zhao, PBDEs, hydroxylated PBDEs and methoxylated PBDEs in bivalves from Beijing markets, Chemosphere 110 (2014) 97-103.

[89] Y. Kato, S. Okada, K. Atobe, T. Endo, F. Matsubara, T. Oguma, K. Haraguchi, Simultaneous determination by APCI-LC/MS/MS of hydroxylated and methoxylated polybrominated diphenyl ethers found in marine biota, Anal. Chem. 81 (2009) 5942-5948.

[90] R.A. Hites, Electron impact and electron capture negative ionization mass spectra of polybrominated diphenyl ethers and methoxylated polybrominated diphenyl ethers, Environ. Sci. Technol. 42 (2008) 2243-2252.

[91] J.I.G. Alonso, P. Rodriguez-Gonzalez, Isotope Dilution Mass Spectrometry, Royal Society of Chemistry, 2013.

[92] D. Zacs, J. Rjabova, A. Fernandes, V. Bartkevics, Brominated, chlorinated and mixed brominated/chlorinated persistent organic pollutants in European eels (Anquilla anquilla) from Latvian lakes, Food Addit. Contam. Part A 33 (2016) 460-472.

[93] Y. Gong, S. Wen, C. Zheng, X. Peng, Y. Li, D. Hu, L. Peng, Potential risk assessment of polybrominated diphenyl ethers (PBDEs) by consuming animal-derived foods collected from interior areas of China, Environ. Sci. Pollut. Res. 22 (2015) 8349-8358.

[94] W. Ben Ameur, S. Ben Hassine, E. Eljarrat, Y. El Megdiche, S. Trabelsi, B. Hammami, D. Barceló, M.R. Driss, Polybrominated diphenyl ethers and their methoxylated analogs in mullet (Mugil cephalus) and sea bass (Dicentrarchus labrax) from Bizerte Lagoon, Tunisia, Mar. Environ. Res. 72 (2011) 258-264.

[95] Q. Luo, Z.W. Cai, M.H. Wong, Polybrominated diphenyl ethers in fish and sediment from river polluted by electronic waste, Sci. Total Environ. 383 (2007) 115-127.

[96] C. Feng, Y. Xu, Y. He, Q. Luo, J. Zha, Z. Wang, Debrominated and methoxylated polybrominated diphenyl ether metabolites in rainbow trout (Oncorhynchus mykiss) after exposure to decabromodiphenyl ether, J. Environ. Sci. 22 (2010) 1425-1434.

[97] P. Isosaari, A.K. Lundebye, G. Ritchie, Ø. Lie, H. Kiviranta, T. Vartiainen, Dietary accumulation efficiencies and biotransformation of polybrominated diphenyl ethers in farmed Atlantic salmon (Salmo salar), Food Addit. Contam. 22 (2005) 829-837.

[98] H. Wolschke, X.-Z Meng Z Xie, R. Ebinghaus, M. Cai, Novel flame retardants (N-FRs), polybrominated diphenyl ethers (PBDEs) and dioxin-like polychlorinated biphenyls (DL-PCBs) in fish, penguin, and skua from King George Island, Antarctica, Mar. Pollut. Bull. 96 (2015) 513-518.
[99] Q. Li, C. Yan, Z. Luo, X. Zhang, Occurrence and levels of polybrominated diphenyl ethers (PBDEs) in recent sediments and marine organisms from Xiamen offshore areas, China, Mar. Pollut. Bull. 60 (2010) 464-469.

[100] R.S. Lazarus, B.A. Rattner, P.C. McGowan, R.C. Hale, N.K. Karouna-Renier, R.A. Erickson, M.A. Ottinger, Chesapeake Bay fish-osprey (Pandion haliaetus) food chain: evaluation of contaminant exposure and genetic damage, Environ. Toxicol. Chem. 35 (2016) 1560-1575.

[101] G.B. Kim, H.M. Stapleton, PBDEs, methoxylated PBDEs and HBCDs in Japanese common squid (Todarodes pacificus) from Korean offshore waters, Mar. Pollut. Bull. 60 (2010) 935-940.

[102] M. Sprague, J.R. Dick, A. Medina, D.R. Tocher, J.G. Bell, G. Mourente, Lipid and fatty acid composition, and persistent organic pollutant levels in tissues of migrating Atlantic bluefin tuna (Thunnus thynnus, L.) broodstock, Environ. Pollut. 171 (2012) 61-71.

[103] R. Airaksinen, A. Hallikainen, P. Rantakokko, P. Ruokojärvi, P.J. Vuorinen, J. Mannio, H. Kiviranta, Levels and congener profiles of PBDEs in edible Baltic, freshwater, and farmed fish in Finland, Environ. Sci. Technol. 49 (2015) $3851-3859$.

[104] S.A. Morrison, K.K. Sieve, R.E. Ratajczak, R.B. Bringolf, J.B. Belden, Simultaneous extraction and cleanup of high-lipid organs from white sturgeon (Acipenser transmontanus) for multiple legacy and emerging organic contaminants using QuEChERS sample preparation, Talanta 146 (2016) $16-22$.

[105] P.S. Dias, C.V.Z. Cipro, S. Taniguchi, R.C. Montone, Persistent organic pollutants in marine biota of São Pedro and São Paulo Archipelago, Brazil, Mar. Pollut. Bull. 74 (2013) 435-440.

[106] Y. Sapozhnikova, S.J. Lehotay, Multi-class, multi-residue analysis of pesticides, polychlorinated biphenyls, polycyclic aromatic hydrocarbons, polybrominated diphenyl ethers and novel flame retardants in fish using fast low-pressure gas chromatography-tandem mass spectrometry, Anal. Chim. Acta 758 (2013) 80-92.

[107] Y. Sapozhnikova, T. Simons, S.J. Lehotay, Evaluation of a fast and simple sample preparation method for polybrominated diphenyl ether (PBDE) flame retardants and dichlorodiphenyltrichloroethane (DDT) pesticides in fish for analysis by ELISA compared with GC-MS/MS, J. Agric. Food Chem. 63 (2015) 4429-4434.

[108] Y. Sapozhnikova, S.J. Lehotay, Evaluation of different parameters in the extraction of incurred pesticides and environmental contaminants in fish, J. Agric. Food Chem. 63 (2015) 5163-5168.

[109] K. Kalachova, T. Cajka, C. Sandy, J. Hajslova, J. Pulkrabova, High throughput sample preparation in combination with gas chromatography coupled to triple quadrupole tandem mass spectrometry (GC-MS/MS): a smart procedure for (ultra)trace analysis of brominated flame retardants in fish, Talanta 105 (2013) 109-116. 